\title{
Sustaining Wealth: Simulating a Sovereign Wealth Fund for the UK's Oil and Gas Resources, Past and Future
}

\author{
Giles Atkinson $^{\mathrm{a}, \mathrm{b},{ }^{*}, \text { Kirk Hamilton }}{ }^{\mathrm{a}, \mathrm{c}}$ \\ ${ }^{a}$ Department of Geography and Environment, London School of Economics and Political \\ Science, Houghton Street, London, WC2E 2AE, United Kingdom. \\ ${ }^{b}$ Grantham Research Institute on Climate Change and Environment, London School of \\ Economics and Political Science, Houghton Street, London, WC2E 2AE, United Kingdom. \\ ${ }^{c}$ Institute for New Economic Thinking, The Martin School, Manor Road Building, Manor \\ Road, Oxford, OX1 3UQ, United Kingdom.
}

* Corresponding author: Department of Geography and Environment, London School of Economics and Political Science

Email address: g.atkinson@,1se.ac.uk (G. Atkinson)

[Other author email address: k.hamilton@1se.ac.uk]

\begin{abstract}
Exhaustible resources and the revenues they generate present a number of broad problems for macroeconomic management. For example, tax revenues can be large and highly volatile, and the stream of revenues is finite. An increasing number of countries now view resource funds and/or fiscal rules for resource revenues as the answer to these challenges. In this paper, we explore the consequences for the UK if past revenues arising from the depletion of subsoil assets had been channelled into a sovereign wealth fund. We show that had a decision been made to establish such a fund in 1975, this could have been substantial in size by 2018 (about GBP 354 billion) and, moreover, would have had a number of benefits such as a reduction in volatility of resource revenues flowing to the Treasury. Crucially, the fund's value would have substantially boosted the size of the government balance sheet, yielding corresponding fiscal benefits. We argue this missed opportunity is underlined further by considering the current debate about shale gas development in the UK. Notwithstanding considerable uncertainties, favourable and optimistic projections for key parameters are required for any shale-based fund to match what we simulate based on past experience for conventional subsoil assets.
\end{abstract}

Keywords: Sustainability; resource depletion; sovereign wealth funds

Acknowledgements: We would like to thank Renaud Coulomb and Emanuele Campiglio as well as two anonymous reviewers for extremely valuable comments on earlier drafts. 


\section{Introduction ${ }^{1}$}

The recent evidence that the UK may possess sizable resources of shale gas and oil has prompted reflection about whether the UK 'wasted' its North Sea petroleum resources, and whether some form of sovereign wealth fund (SWF) would now be a more effective way to use tax revenues were shale gas and oil resources to be developed. In the current UK context, the significance of this debate depends on the magnitude of the potential shale windfall (e.g. Hilaire, 2018; Andrews, 2013). But, more generally, exhaustible resources and the revenues they generate present two broad problems for macroeconomic management: gross production and tax revenues can be large and highly volatile, and the stream of revenues is finite, ending when the resource deposit ceases to be economic.

An increasing number of countries or jurisdictions do appear to view resource funds and/or fiscal rules for resource revenues as an answer to such challenges (Hamilton and Ley, 2011; Cummine, 2016). As Ossowski et al. (2008) argue, some combination of a natural resource fund - of which a SWF is one variant - and fiscal rules on the use of resource revenues can reduce pro-cyclical tendencies and provide investments and savings to support future wellbeing in extractive economies (see also, for example: van der Ploeg, 2014, Hassler et al. 2015; Clark et al. 2013 as well as Segal, 2012, and Martinez-Oviedo and Medda, 2017, for discussions of how to spend resource revenues). ${ }^{2}$

Ossowski and Halland (2017) review the functions that SWFs can serve for the fiscal authorities. This includes: long-term savings and pension reserve funds - the finite stream of revenues from exhaustible resources can be invested in financial assets yielding benefits over the long term; budget stabilization - a SWF can buffer revenue volatility in addition to financing government priorities; foreign exchange management - many resource exporting countries accumulate large international reserves as a result of exporting natural resources. Managing these reserves to increase returns on foreign currency holdings can be another feature of a SWF; national development and portfolio management-some SWFs are permitted to invest in domestic fixed assets or financial assets on a commercial basis. This list

\footnotetext{
${ }^{1}$ Declarations of interest: none.

${ }^{2}$ An alternative model for a fund is an earmarked pot with which to finance projects identified 'now' as being productive investments (van der Ploeg, 2014). For example, this investment might be in domestic produced capital, human capital or even natural capital.
} 
highlights the multiple functions that SWFs can provide as well as some potential conflicts between functions. ${ }^{3}$

A related feature of a well-managed SWF is the expansion of the public sector balance sheet as resource revenues are invested in foreign financial assets. Recent work by the IMF (2018) focuses on the benefits that can accrue to countries with strong public sector balance sheets. For example, there is evidence that financial markets consider the balance sheet size as well as public sector debt in establishing borrowing costs (Hadzi-Vaskov and Ricci 2016; HenaoArbelaez and Sobrinho 2017 for developing countries, and Gruber and Kamin, 2012 for advanced economies). Countries with stronger balance sheets may pay lower interest on their debt (see, IMF, 2018 Box 1.2) and may even experience shorter and shallower recessions compared to countries with less healthy balances. Detter and Fölster (2015) argue that better management of the balance sheet (both financial and fixed assets) can increase fiscal revenues.

Given that North Sea revenues reached 9.9\% of fiscal revenues and 3.7\% of GDP in 1984, with revenues exceeding 1\% of GDP from 1979 to 1987, in this paper we ask what the UK lost in not establishing some form of SWF in terms of the public finances and the public balance sheet. By examining several key aspects of the North Sea experience in the light of this question, the contribution of this paper is the following.

First, we show how asset accounting is a critical ingredient in all of this, as it yields a measure of resource rents and depletion values generated by resource extraction, which may be subject to taxation (Hamilton, 2016, UN, 2013; Obst and Vardon, 2014) and throws light on the overall sustainability of the economy by enabling the calculation of depletion-adjusted net saving (UN, 2013; Hamilton and Hartwick, 2014). Our assessment of the effectiveness of resource taxation in the UK is relatively positive (in contrast to e.g. Abdo, 2010): on average over $65 \%$ of resource rent and $82 \%$ of resource depletion values were captured by taxes and royalties over 1975 to 2018 . That said, our findings on the sustainability of the economy are less encouraging - for the same period we calculate depletion-adjusted net national saving for

\footnotetext{
${ }^{3}$ In particular, investment in domestic fixed or financial assets can undermine the integrity of the budget process because politicians may be inclined to choose favourites. Appreciation of the exchange rate can also occur as resource revenues are converted to domestic currency for investment purposes.
} 
the UK, and conclude that on average this measure is less than 5\% of GDP and it approaches 0 or is negative in some years.

Second, we simulate a SWF for investing these resource revenues over the period 1975 to 2018. This is a simplified version of the Norwegian Government Pension Fund for the UK a saving and pension reserve fund as described by Ossowski and Halland (2017) - where we assume resource revenues were invested in a global portfolio of financial assets, and that the fund paid out a fixed percentage of assets to the Treasury from 1975 to $2018 .^{4}$ This simulated SWF shows that sacrifices in terms of foregone current revenues to the Treasury would have been large, over the years 1979 to 1987. After 1988, however, payouts from the SWF would have exceeded resource revenues (with minor exceptions). The volatility of payouts from the fund would also have been much lower than the volatility of resource revenues.

Third, we show the value of the fund would have substantially boosted the size of the government balance sheet by 2018 . While this is based on a partial analysis rather than a full counterfactual scenario for government finances in the presence of a SWF, ${ }^{5}$ we build on IMF (2018) in order to demonstrate a link between our findings and a fuller picture of national net worth, including the public sector. Our result here indicates the role a SWF might have had in strengthening the balance sheet at a critical juncture in the 2000s. The scale of this missed opportunity is underlined further by considering the current debate about shale gas development. We argue it is likely to require favourable projections for recoverable resources, prices and resource revenue capture for any future fund to match what we simulate based on past experience for North Sea petroleum resources.

The rest of this paper is organized as follows. Second 2 immediately below discusses data and methods. Section 3 presents an account for oil and gas assets in the UK over the period 1975-2018 and benchmarks resource revenues against the value of resource depletion.

\footnotetext{
${ }^{4}$ Our analysis therefore builds on Hawksworth (2008) which calculates that the UK could have had a fund of some GBP 450 billion (an amount greater than the tax revenues collected over the period of that study). Scottish Government (2009) also simulate the establishment of a (hypothetical) past fund by assuming different (but relatively modest) percentages of tax revenues being invested as well as different rates of return. Cummine (2016) and Atkinson (2016) also discuss a SWF in the UK context and North Sea Oil and Gas revenues. ${ }^{5}$ Since there is little economic logic to simultaneously increasing debt and paying resource revenues into a SWF, the implication is that a counterfactual would have to include reductions in public expenditures and/or increases in non-petroleum revenue, especially in the early 1980s. There is an element of endogeneity at work here as well, since the availability of resource revenues may have led government to reduce or restrain taxation of the non-petroleum economy.
} 
Section 4 models, and reflects on, the size of a hypothetical SWF based on historical resource revenues to 2018, as well as a tentative assessment of a future fund for shale gas and oil resources in the UK. Section 5 discusses and concludes.

\section{Data and Methods}

Our primary objective, in this paper, is to evaluate how the UK's petroleum assets might have contributed to sustainability and the public finances in recent decades. In doing so, we use wealth accounting (and specifically, resource asset accounting) for asset values of oil and gas over the period 1975-2018. We also simulate a sovereign wealth fund (SWF) to characterise how resource revenues (the fiscal revenues resource production accruing to HM Government over the period) might have accumulated were these explicitly invested in financial assets. While this fund is hypothetical, we further comment on the potential magnitude of a SWF were it to be started 'now' based on future UK conventional and unconventional petroleum resources. Our data and methods in this regard can summarised as follows:

Resource asset account: The petroleum asset account constructed here is based on standard resource accounting principles as laid out in the United Nations System of Environmental and Economic Accounts (UN SEEA) (UN 2013). The starting point is an estimate of resource rents, which are measured as the difference between resource revenues and the economic cost of extraction, which includes current extraction costs, depreciation and the opportunity cost of fixed capital as well as (current) decommissioning costs. We use data in OGA (2019a) as well as ONS (various) to estimate our resource asset account. A complication of these UK data is that there are no separate extraction cost estimates available for natural gas. We therefore use the oil extraction costs in estimating resource rents, and treat gas as a coproduct of oil extraction. Resource revenues in the rent calculation are therefore the sum of revenues from oil and gas extraction.

Resource asset values are calculated as the present value of resource rents up to the point of exhaustion. Physical reserves are measured as the sum of proven and probable resources. For purposes of the present value calculation, resource rents are fixed at the current year and held constant up to the point of exhaustion. This is how resource asset values are typically estimated, although in some instances governments use specific forecasts of prices, costs and quantities extracted (see, for example, Kahn et al. 2013). The key assumptions and 
parameters used in estimating petroleum asset values are shown in Table A1.1 in Annex 1 to this paper. The rate of return used to establish the opportunity cost of fixed capital is equal to the 10 year moving average of interest rates on government bonds as measured in 2013, while the discount rate is the recommended rate from the UK Green Book for cost-benefit analyses covering periods of 30 years or less (HM Treasury, 2018). For simplicity we assume these rates to be fixed from 1975 to $2018,{ }^{6}$ which may lead to minor differences between our asset estimates and any values published by the UK Office for National Statistics (ONS).

As stipulated in the SEEA, the value of depletion of petroleum is measured as the unit value of depletion times the quantity extracted (where, again, gas is measured in tonnes of oil equivalent). The unit value of depletion is equal to the current resource asset value divided by the current physical stock. ${ }^{7}$ The resulting resource asset account estimates can be found in Annex 1 (Table A1.2).

Where these resource asset account data are examined in the context of the broader UK economy - notably when we estimate depletion-adjusted net saving - we additionally draw on data published in ONS (various).

Simulated SWF - 1975 to 2018: Data on resource revenues from 1975 to 2018 are taken from the database in OBR (various) and used to simulate a fund on the basis of three principles: (a) all petroleum revenues are paid into the fund; (b) revenues are invested in foreign financial assets; and, (c) payouts from the fund to the Treasury are at a fixed percentage rate each year. The fixed payout rate we use is based upon aggregate long-run real rates of returns on assets in major economies from 1900 to 2018 (Credit Suisse, 2019). We assume that the fund is fully invested in a 'moderate growth' global portfolio of $60 \%$ equities and $40 \%$ bonds, which yields a mean real rate of return of $3.76 \%$. This is an application of the Norwegian Government Pension Fund approach to saving petroleum revenues to UK data. As the largest and one of the most enduring SWFs in the world, this provides a useful model. ${ }^{8}$

\footnotetext{
${ }^{6}$ These are respectively $4.3 \%$ and $3.5 \%$.

${ }^{7}$ Note that this methodology implicitly accounts for resource discoveries. As shown in Hamilton and Atkinson (2013), as long as resource rents are assumed to be constant over the resource lifetime, the unit value of depletion declines when there is an increase in the physical stock owing to discoveries. Other things being equal therefore, a depletion-adjusted measure of Net National Income rises when new resources are discovered.

${ }^{8}$ Note that in Norway's case, petroleum resource revenues were large relative to central government expenditure from the outset. The policy rule in Norway is to invest petroleum revenues in excess of the non-oil budget deficit in the petroleum fund. Over time the petroleum fund grew to the point where fiscal policy now aims for a non-oil deficit equal to $3 \%$ of the value of the fund, which represents the real return on the assets in
} 
The simulation of the fund is straightforward. The net value of the fund at the end of the preceding period is equal to the gross value minus the payout on the gross value. The gross value of the fund at the end of the current period is therefore equal to current resource revenues, plus the net value of the fund at the end of the preceding period times 1 plus the nominal rate of return on assets in the current period. A complication in the simulation is that only long run averages are reported in Credit Suisse (2019), while the underlying (DimsonMarsh-Staunton) data on real returns by country by year are proprietary. We are therefore forced to construct a synthetic annual nominal rate of return for the UK SWF as the sum of the long-run aggregate real return on assets plus the rate of inflation in the UK economy as measured by the GDP deflator. The synthetic nominal returns can differ considerably from actual returns in any given year because the assumed constant real rate of return on assets introduces a strong element of smoothing in the calculation. As Credit Suisse (2011) shows, the long run volatility of global financial assets is considerable, with a standard deviation of $17.7 \%$ for returns on equities and $10.4 \%$ for bonds. Over the long run, however, the value of the smoothed fund should be close to that of a fund based on nominal returns. We explore the implications of volatility in actual returns in subsequent discussion based on US data (Section 4 and Annex 2). We also examine an alternative procedure for simulating our SWF based on a permanent income approach (Section 4 and Annex 3).

SWF for (future) shale gas and oil: To frame further our findings on the missed opportunity of a past SWF, we speculate on the magnitude of a fund based on potential (albeit, uncertain) development of unconventional resources in the UK in the future: e.g. on-shore shale gas and oil resources. The basis of this is recent studies undertaken by the British Geological Survey (BGS) which provide a geological assessment of those areas identified as having considerable potential prospectivity within: (a) the North UK Carboniferous Shale Region: geological basins and troughs across northern England and southern Scotland (Andrews, 2013; Monaghan, 2014); and, (b) the South UK Jurassic Shale Region: basins in Southern England and offshore into the English Channel (Andrews, 2014; Greenhalgh, 2016). Table A1.3 in Annex 1 to this paper summarise these data.

the fund assumed by the Norwegian government. This is effectively a 'bird-in-hand' rule. The Norwegian Government Pension Fund initially invested in low-risk fixed income, but currently invests in a portfolio consisting of $60 \%$ equities and $40 \%$ fixed income, which is the portfolio composition that we assume in our simulation of a UK SWF. 
While these data provide a relatively granular geological assessment, these refer to a metric of resource extent which is extremely broad: resources-in-place or the total quantities reckoned to be physically contained in source rock (US EIA, 2013). As such, it encompasses resources which may not ultimately be recoverable (either technically or economically) and so is best interpreted as circumscribing upper bounds given existing geological knowledge. To calculate a speculative SWF based on these undeveloped shale gas and oil resources, we rely on a range of assumptions about ultimate recoverability in combination with assumed values for resource prices (in GBP 2015) from both our historical series (1975-2018) and the trajectory of prices used in forecasts by BEIS (2017). ${ }^{9}$ Two final parameters in this calculation are the share of total rent in the production value of unconventional resources. Our assumed range for proportion of total rents captured in the form of resource revenues is also drawn from our historical series. These data and assumptions are summarised in Table A1.4 in Annex 1.

\section{Accounting for UK Oil and Gas}

\subsection{UK Petroleum Assets and Sustainability}

Measuring the value of resource depletion is an essential input into policies for sustainable development in extractive economies. The Hartwick Rule (Hartwick 1977) shows that future consumption can be sustained when exhaustible resources are extracted if other investments offset the value of resource depletion. Hamilton and Clemens (1999) show that wellbeing cannot be sustained if 'genuine' saving, including the value of resource depletion, is negative. This forward-looking strategy for saving has parallels too with the permanent income hypothesis (see, for example, van der Ploeg, 2014).

The practical link between changes in total wealth and sustainability was first explored by Pearce and Atkinson (1993). Subsequent growth theoretic literature, including Hamilton and Clemens (1999), Dasgupta and Mäler (2000) and Asheim and Weitzman (2001), has

\footnotetext{
${ }^{9}$ In effect, we assume that oil and gas prices are positively coupled. Erdös (2012), for example, examines the (de)coupling of oil and gas prices in the US, Europe and UK. In the case of the latter at least, the author finds these were broadly in convergence over the period 1972 to 2014, which seems to give some support to this assumption.
} 
elaborated the theoretical foundations for this approach to measuring sustainability. The World Bank publishes figures on Adjusted Net Saving (ANS) going back to 1970 for over 150 countries in the World Development Indicators. This extended measure of the change in real wealth includes not only resource depletion but also investments in human capital (via education expenditures) and damages from pollution exposure (see, also Hamilton and Atkinson, 1996 for early estimates for the UK on these lines). While excluding education expenditures and pollution damages, the SEEA recommends two extended national accounting aggregates - depletion-adjusted net saving and net income.

\section{Figure 1: Depletion-adjusted Net Saving in the UK (\% of GDP)}

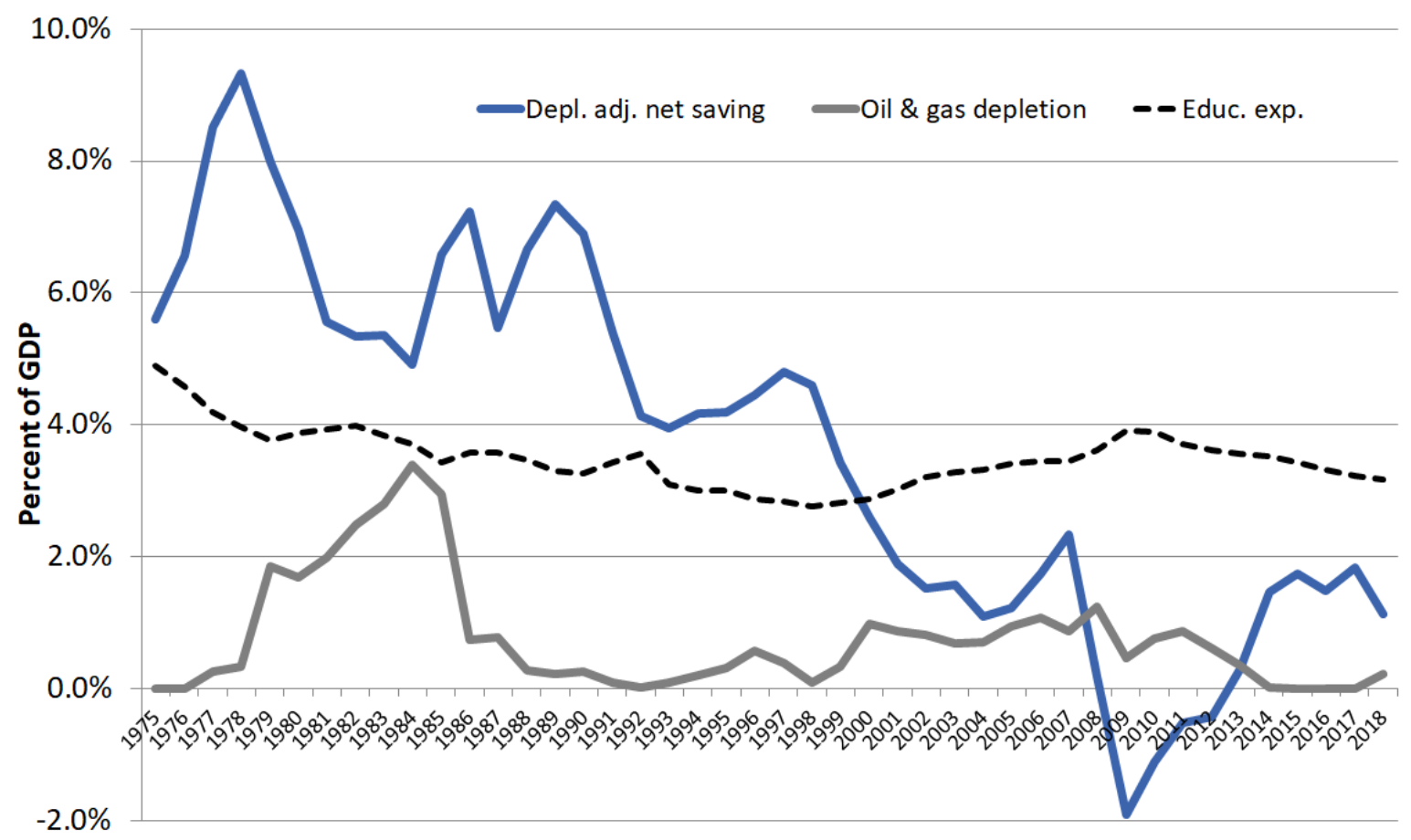

Source: authors estimates from ONS (various)

In Figure 1, we comment on asset accumulation and wealth more generally for the UK. A key measure here is depletion-adjusted saving which is low but positive (under 5\% of GDP, with a declining trend) for much of the period. ${ }^{10}$ However, depletion-adjusted net saving briefly dips when the value of resource depletion was at its highest in the 1980s and again for a more

\footnotetext{
${ }^{10}$ This is likely to overstate genuine saving which as previously mentioned includes a range of pollution damages such as the social cost of carbon. Put another way, UK sustainability is likely to be overstated here. However, we use the UN SEEA standard of depletion-adjusted net saving in order to focus upon saving net of oil and gas depletion.
} 
prolonged period from 2000 onwards. ${ }^{11}$ Indeed, in two of the latter years, depletion-adjusted saving is negative.

Of course, some portion of what officially comprises government consumption may also have constituted investment in intangible wealth, particularly expenditure on education (see, for example, Cummine, 2016). Figure 1 plots government spending on education over the period. On average, these expenditures were about 3.5\% of GDP from 1975-2018 with slightly higher percentages at the beginning of this period. Education expenditures (relative to GDP) do not seem to be higher in the wake of higher resource depletion values. In fact, from 1979 to 1985 education expenditures decreased by $-0.23 \%$, in real terms, on average per annum (ONS, various). This is considerably lower than the average annual increase (1.2\%) for 1975 2018. By contrast, non-education government consumption expenditure (not shown here) increased by about $3.4 \%$ per annum over $1979-1985$.

\subsection{Accounting for Government Resource Revenues}

Highly aggregated insights about the sustainability of the economy take us only so far. Relating this asset accounting to the public finances is also important given that a critical pathway for boosting savings from resource depletion arises from appropriating these benefits through the tax regime.

This tax regime, established in the Oil Taxation Act of 1975, has evolved substantially over subsequent years (HMRC, 2008; Kemp, 2011a,b) and now consists of two (field-based) charges applied to the net profits ${ }^{12}$ of producers: Petroleum Revenue Tax (PRT) and Corporation Tax (CT). These charges themselves have undergone a number of revisions over the years, and PRT does not apply to fields developed after March 1993. ${ }^{13}$ A number of other taxes have applied at earlier stages of the period we examine (Abdo, 2010; Nakhle, 2008). A

\footnotetext{
${ }^{11}$ Recent updates in ONS (various) have changed procedures of accounting for depreciation of produced capital (as well as stocks). This has had the effect of boosting these estimates, compared to the previous procedure. However, data using this new method are available from 1987 only. Figure 1 utilises data on produced capital depreciation from 1975 to 1986 which use the old procedure and, in effect, our savings estimate is understated until 1987 because of this discrepancy.

12 Defined as the value of production net of allowable capital and operating expenditures.

${ }^{13}$ The tax rates for both PRT and CT have also undergone a number of revisions. PRT rates have been $45 \%$ (until 1978), 60\% in 1978, 70\% from 1979 before reaching a peak of 75\% level in 1983. From 1993, this was reduced to $50 \%$ although in 2016 the rate - from that point on - was reduced to zero (although PRT still exists as producers can claim relief on past payments given decommissioning costs). CT for resource producers has tracked the standard corporation tax, from 2002. But this was complemented by a further supplementary charge introduced at $10 \%$ but increased from the beginning of 2006 to $20 \%$ and to $32 \%$ in 2011 .
} 
'Royalty' amounting to a charge on the gross value of oil and gas (less allowable deductions) produced applied to fields licenced before 1982 only and was discontinued altogether by 2002. In addition, two ad hoc charges (established in 1981) were Supplementary Petroleum Duty (SPD) and a Gas Levy (on otherwise tax exempt gas). The former was short-lived and abolished after two calendar years while the latter was phased out after the late 1990s.

On average, these resource revenues contributed $2.2 \%$ of total government revenues over the period 1975 to 2018 . This average is skewed by the tax proceeds accruing in the 1980 s where this amounted to $5.6 \%$ of total revenues on average (and $8.2 \%$ on average from 1981 to 1985). The relative importance of the different tax instruments discussed previously has changed over the years. Most notable was the relative importance of PRT in the late 1970s and much of the 1980s and the role of the CT as the principal instrument used to collect resource revenues in the oil and gas sector in the later years of our study period.

Figure 2: Resource Revenues in Comparison to Depletion Values (GBP million, 2018)

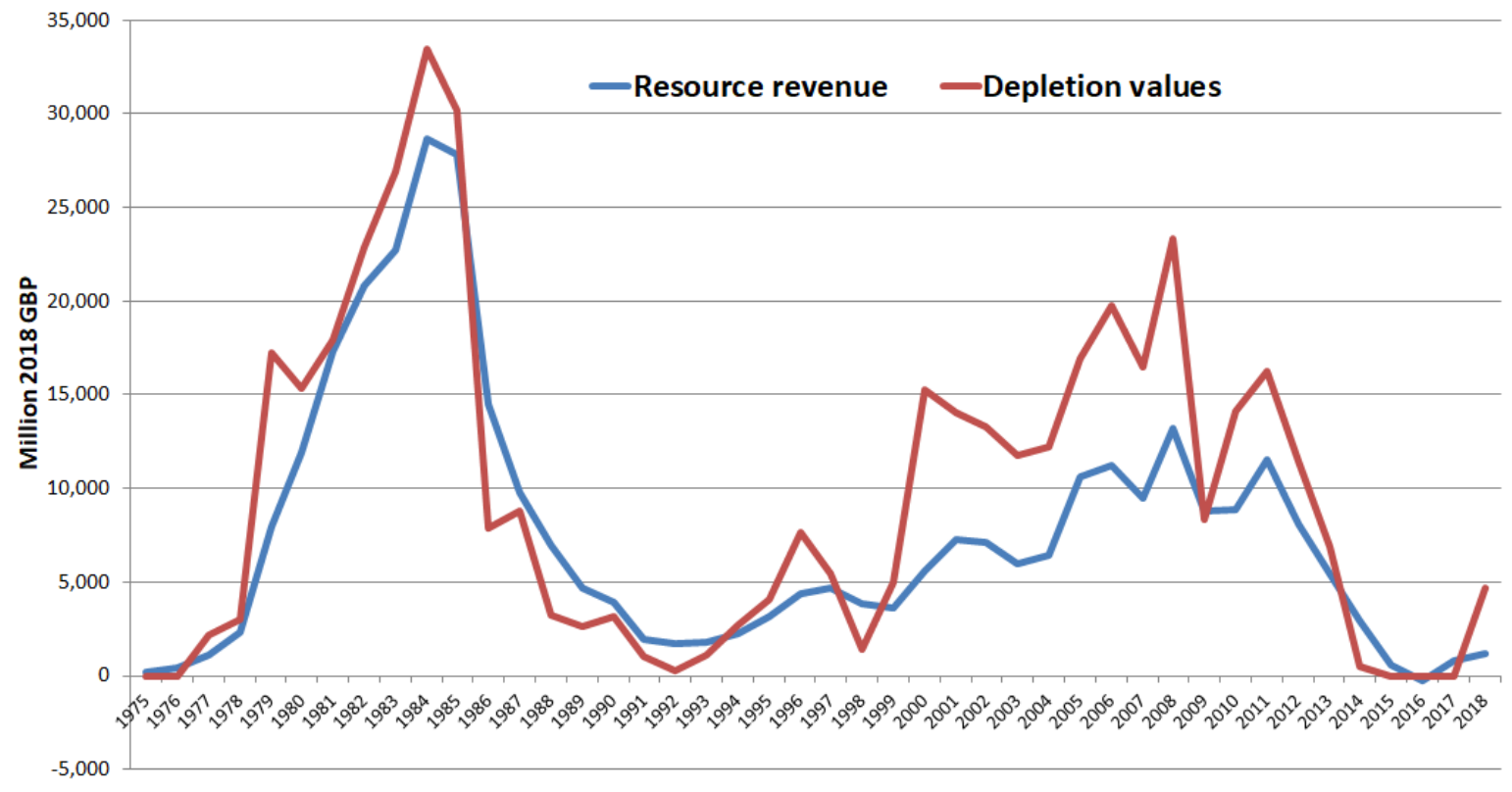

Source: OBR (various) and authors estimates from ONS (various)

Figure 2 compares revenues with depletion values since, according to the theory outlined above, this is the portion of total resource rents which must be invested in other assets if sustainability is to be achieved. What is striking is that the two series track one another reasonably closely indicating the extent to which these resource revenues have succeeded in 
capturing depletion values. On average, this amount captured through taxation corresponds to about $82.3 \%$ of depletion values from $1975-2018$ (which, in turn, corresponds to $65.6 \%$ of resource rents over the same period). While this tax regime has been critiqued on the grounds of being dominated by short-term macroeconomic policy and creating uncertainty for resource exploration and development (Kemp, 2011a; Nakhle, 2008), it appears to have been effective in capturing depletion values.

What this asset accounting misses is whether these depletion values were optimal (which would require that marginal resource rents rise at the rate of interest - the Hotelling Rule). Moreover, while the average performance of the tax regime is important, so is its variability. Abdo (2014) situates this in a governance context by distinguishing between 'proprietorial' and 'non-proprietorial' (fiscal) regimes over this period in the UK. In the former a primary objective for government is capturing for the public benefit the proceeds of resource depletion. In the latter, government adopts a lighter fiscal regime in order to enhance incentives to deplete known reserves as well as invest in exploration activities.

Both objectives are articulated in HMRC (2008). The central argument in Abdo (2014) is that different weight has been placed on each by UK Government over the years: that is, up to 1983, this fiscal regime is characterised as proprietorial, and thereafter was non-proprietorial with a movement back to a proprietary stance after 2002. To what extent can the trends in Figure 2 be understood in this light of this? In the 1980s it seems that resource revenues tracked closely depletion values and indeed the tax regime over-performed in respect of a criterion to at least capture this value, albeit in the context of declining depletion value. By contrast, from 2000 onwards (and to some extent starting the mid-1990s) there was substantial divergence, with tax revenues falling short of depletion values at least until towards the end of study period.

Figure 2 plots revenue data from all production fields (which differ by development date and thus fiscal regime). Moreover, there is likely to be a lag between fiscal policy change and ensuing revenues. Abdo (2010), for example, concludes that the UK tax regime allowed companies in the UK continental shelf to accumulate, and retain, substantial profits in the period 2002 to 2007 but that, importantly, this can traced back to a series of measures beginning in the early 1980 s, mostly introduced with a view to creating greater incentives for private investment activities. A clear implication of Abdo (2010, 2014) - echoing an earlier 
contribution on these lines by Rutledge and Wright (1998) - is that the UK government may have sacrificed potential resource revenues.

\section{Simulating a Sovereign Wealth Fund for the UK}

The technique we use to simulate a UK SWF is based on the 'bird-in-hand' approach employed by the Norwegian Government Pension Fund. This directs all petroleum tax revenues to a fund invested in foreign financial assets; the fund then pays out investment returns to government general revenues. The key alternative to the bird-in-hand model is the 'permanent income approach', whereby the finite stream of resource revenues is converted to a constant stream of payments to the fiscus over the indefinite future. This is achieved by investing an increasing share of resource revenues in a SWF, so that the resulting constant income is a mixture of tax revenues and returns on the SWF. We apply this model to the UK data in Annex 3. As seen in this Annex, the two approaches yield divergent outcomes. The permanent income approach, as expected, yields revenues which can be transferred to general government receipts especially in initial periods. The bird-in-hand approach initially has a greater opportunity cost (in terms of foregone revenues) but yields a larger fund, and so provides larger returns later on and into the indefinite future.

The permanent income model is typically recommended for developing countries because the welfare costs of delaying benefits from the resource windfall are high in the poorest countries. These countries can also suffer from institutional weakness, leading van der Ploeg (2017) to lay out a series of guidelines - or government commitments - that developing country governments should make to ensure long term sustainable benefits to the country from petroleum discoveries. These commitments include an intergenerational fund invested in foreign financial assets, a liquidity fund to deal with resource price volatility, and an investment fund aimed at domestic public investments, taking account of country absorptive capacity. The bird-in-hand model is better suited to higher income countries who can afford to delay the benefits from a resource discovery.

One of the potential benefits of establishing a SWF in countries with a resource windfall is an increase in the sustainability of development (defined as a development path where national wellbeing is non-decreasing). The canonical model for achieving this outcome is the Hartwick Rule (Hartwick 1977) with its famous dictum: invest resource rents. As generalized 
in Hamilton and Withagen (2007) and Hamilton (2016), if policy ensures that 'adjusted' net saving is non-negative and growing at a rate less than the interest rate along the development path, then welfare will be non-decreasing along the path. Savings can be invested in a wide range of assets including produced capital, human capital and intellectual capital. Our analysis of the UK petroleum resource asset account in Section 3 is closely linked to the question of sustainability, since we show that depletion-adjusted net saving dropped sharply in the early 2000's, actually turning negative, before recovering in 2011.

Simulating a bird-in-hand SWF for UK petroleum exploitation starting in 1975 offers some useful insights. First, investment of resource revenues in a SWF is by its nature a step toward sustainability because it increases saving. But extracting a quantity of petroleum is equally, by its nature, a step away from sustainability because extraction represents dissaving. The net effect of establishing a SWF on sustainability therefore depends on the relative size of these two effects. We would expect resource taxation to be less than the resource rent - otherwise the private sector has no interest in investing - while Hamilton (2016) shows that the value of resource depletion will be less than total resource rent under SEEA accounting standards. Policies to increase sustainability in the context of a SWF must therefore aim for resource taxation that falls between the value of resource depletion and total resource rents on extraction. However, any analysis of sustainability with a SWF must assume 'other things being equal'. In practice, policies leading to dissaving in the private and public sectors could conceivably offset any net saving associated with the operation of the SWF.

\subsection{Looking Back on 1975 to 2018}

To understand the potential benefits of a SWF for the UK, we simulate a fund established in 1975 and track its size and returns paid out to the Treasury up to 2018. This provides estimates of the sacrifices entailed by the fund (years when resource revenues exceeded fund payouts), the long-run potential payout from 2018 onwards, and the reduction in volatility of revenues into the Treasury when fund payouts are compared to current resource revenues. Based on the smoothed accounting assumed in our approach, the simulated value of the fund totals around GBP 354 billion in 2018 (nominal). Using produced capital assets as a comparator, the hypothetical fund value amounts to $7.8 \%$ of total produced assets in the UK in that year, but would exceed the value of produced assets in the central government balance sheet (e.g. ONS, 2019). 
Figure 3: Resource Revenues and Returns from a (Simulated) SWF (GBP million, 2018)

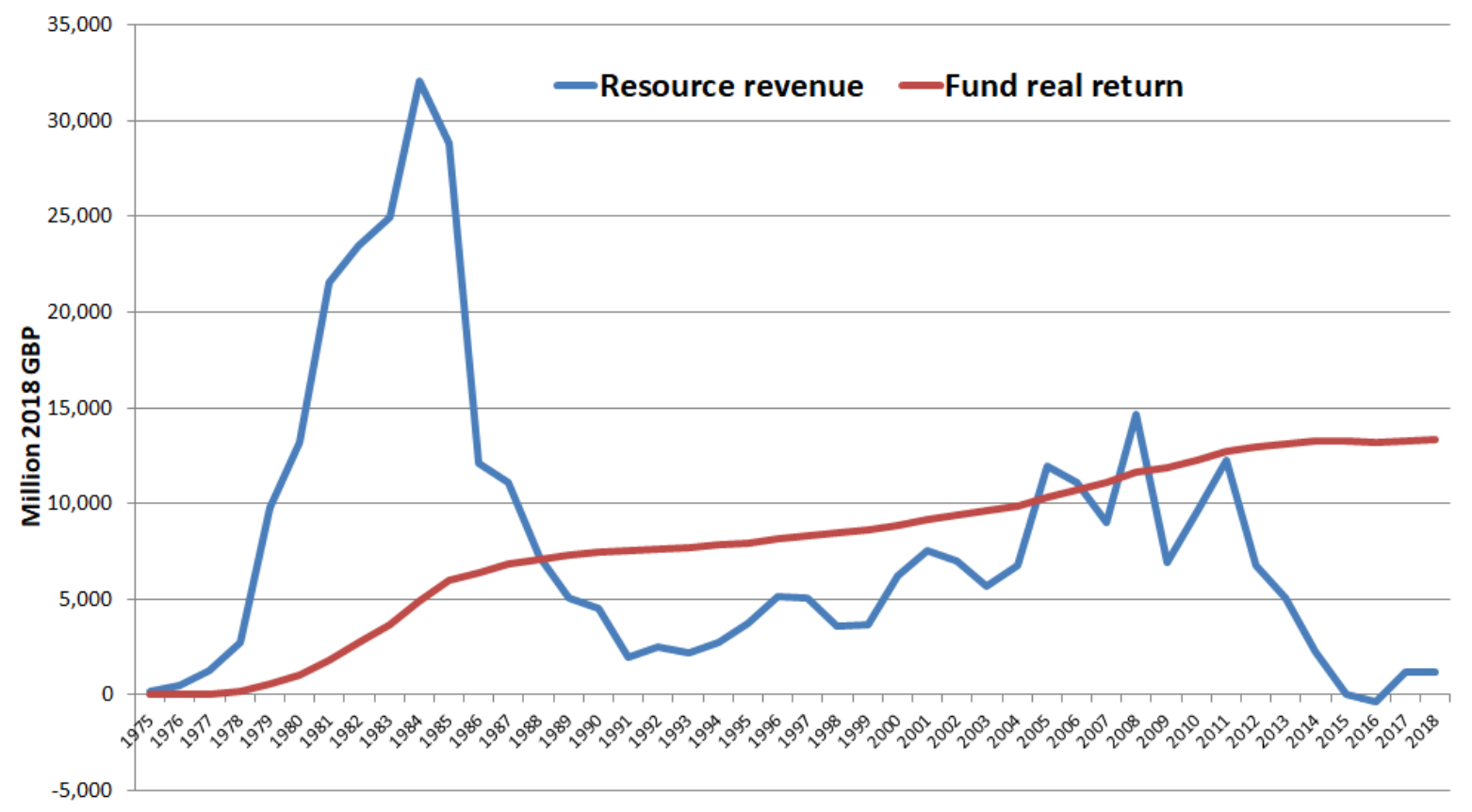

Source: OBR (various) and authors estimates

Figure 3 plots the evolution of resource revenues and the value of the payout from the simulated fund from 1975 to 2018. Two key conclusions follow:

First, the payouts from the SWF are less volatile than annual resource revenues, and payouts exceed resource revenues from 1988 onward (with two minor exceptions). This is to some extent an artefact of the smoothing introduced by our synthetic calculation of nominal returns. In Annex 2 we simulate a UK SWF that invests all of its revenues in US stocks and bonds, building upon historical data on nominal returns on US financial assets (Damodaran, 2014). This fund is compared with a SWF that also invests in US financial assets but uses a synthetic nominal return as constructed for the SWF underlying Figure 3. The simulation in Annex 2 shows that the resource fund buffers revenues and thereby reduces the volatility of flows to the Treasury. Yet there is a partially offsetting source of volatility in the form of year to year variation in the nominal returns on investment in the portfolio of the SWF, which would affect the total value of the fund at any given time. Specifically, the standard deviation of year to year changes in flows is, indeed, considerably higher for resource revenues. It is nearly 3 times more volatile than for the fund simulated using nominal rates of return, and over 6 times more volatile than for the fund using synthetic estimates of nominal returns. 
Second, resource revenues were much larger than the payout from the fund from 1979 to 1986, the period following the second oil crisis. While a slow buildup of payouts is a natural property of a 'bird-in-hand' fund, reflecting the time needed to accumulate significant financial assets, this result indicates the considerable short-run sacrifices that government would have had to make in implementing the fund. The compensation for this sacrifice would be a fund that continues to make annual payouts of tens of billions of pounds to the Treasury long after the North Sea petroleum deposits have ceased to be in production. ${ }^{14}$

Given the current prevalence of SWFs in a growing number of resource-abundant countries, it is worth asking why the UK chose not to establish a fund. Kemp (2011a,b) provides a thorough review of the relevant official historical documents (including British Cabinet minutes and papers) providing formal records of this decision, in the late 1970s. His account indicates a wide-ranging debate in Government, ${ }^{15}$ but perhaps most notably at no time did it consider intergenerational equity, as a guiding principle for managing the resource windfall. This focus came more to the fore, it appears, in the early- to mid-1980s in a series of contributions by the Bank of England (BoE 1980, 1982 and, later, 1986), which explicitly recognised that large resource revenues were generated by a 'wasting asset' and as such: “... would require investment of sufficient of the revenues to maintain the real value of the capital." (BoE, 1982, p56). ${ }^{16}$

Of course, these discussions took place in a difficult economic context, particularly in the early 1980s (see, for example, Bean, 1987). Kemp (2011a) notes a significant element of the economic strategy of the in-coming Conservative administration in 1979 was to use resource revenues to support its macroeconomic policy and reduce public borrowing. HM Government Budgets from 1979 reduced both basic and higher rates of income tax, while the tax rate on

\footnotetext{
${ }^{14}$ In principle, a fund and its flow of returns could be utilised broadly and on the basis of some decision rule governing public spending. In practice, some portion of returns might be earmarked. For example, Abdo et al. (2018) discuss liabilities arising from decommissioning costs of oil and gas related infrastructure in the North Sea. For example, a report by OGA (2019b) estimates these costs to be around $£ 49$ billion. Such sums are clearly substantial, but are the responsibility of private sector oil and gas operators. Nonetheless, NAO (2019) note that HM Government (and so taxpayers) are ultimately responsible for these liabilities if private operators, for some legal reason, cannot meet their obligations (such as through insolvency).

15 This included debate about the appropriate scale of a fund (e.g. would it be a repository for all resource revenues or just some smaller proportion); the expenditure it could facilitate (i.e. discrete investment projects or reducing external debt burdens) and whether this hypothecation of tax revenues would misallocate resources by possibly divorcing these spending decisions from normal fiscal processes.

${ }^{16}$ Odling-Smee and Riley (1985) examines this same issue from the perspective of the UK Treasury and the role of resource revenues in improving public finances.
} 
corporations was considerably reduced from 1984. Resource tax rates meanwhile rose, with the PRT rate levied on oil and gas was increasing in 1979, 1980 and 1982. As a result, resource revenues increased from 3.5\% of central government tax receipts in 1979 to peak at almost $10 \%$ in 1984 .

\section{Figure 4: Non-resource Tax Revenues and Government Expenditure in the UK 1975-} 1985

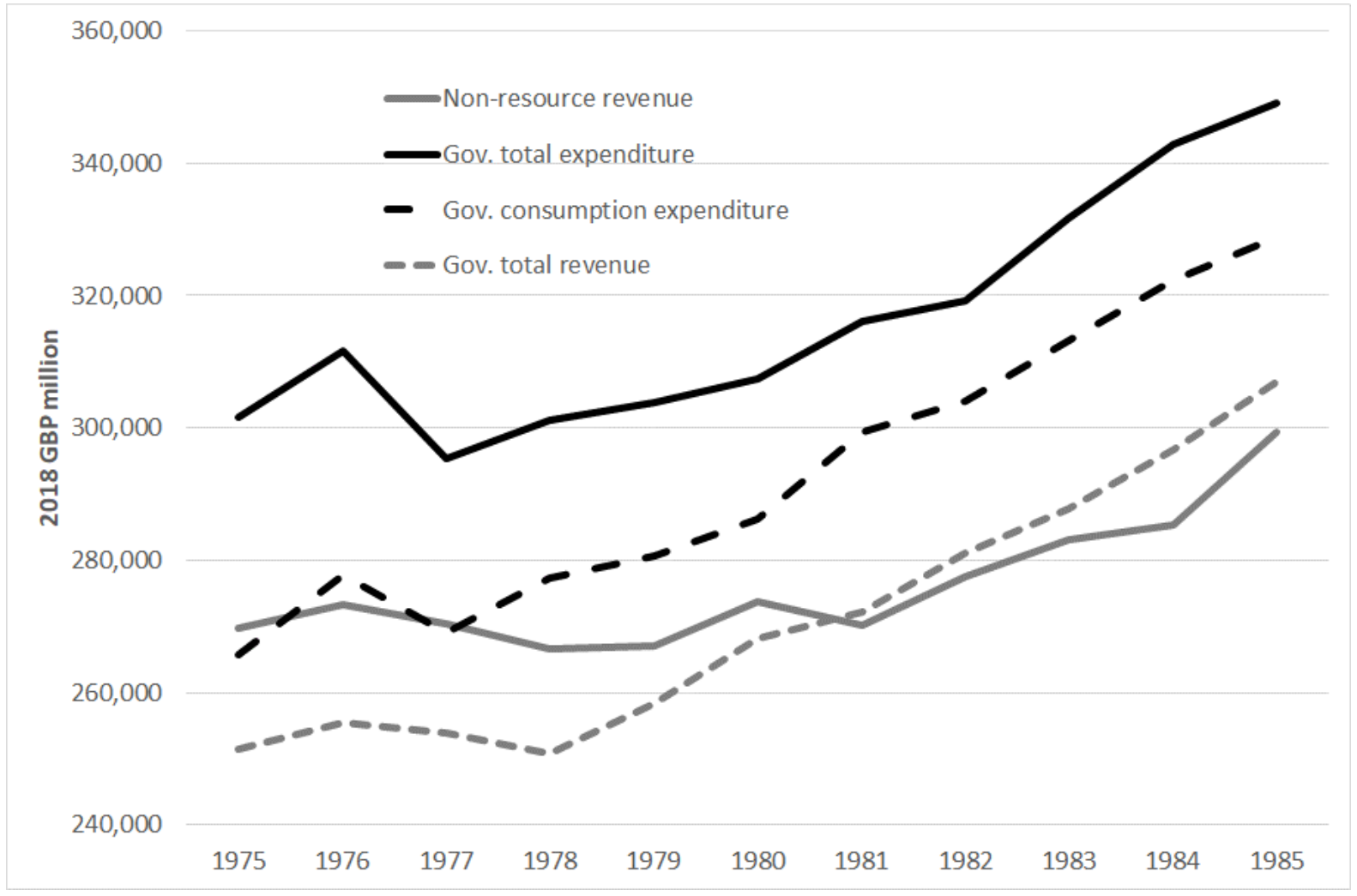

Source: OBR (various) and ONS (various)

The fiscal consequences of investing all resource revenues in a SWF in the early 1980s would have been correspondingly large. To illustrate this, Figure 4 focuses on the first decade of oil production. Both government consumption and total expenditure grew strongly (in real terms) from 1975 to 1985 . There was a flattening of non-resource revenue from 1975 to 1979, and it grew more slowly than total and consumption expenditure afterwards. Because money is fungible there is no unambiguous way to determine how resource revenues affected the main fiscal aggregates historically. The figure makes clear, however, that resource revenues were a significant contributor to total government revenue from 1981 to 1985.

Considering the counterfactual for public finances over 1975-1985, if government were to invest all resource revenues in a SWF while avoiding additional borrowing, it would have 
had to decrease expenditure or increase non-oil revenue (or some combination of the two) by a considerable amount compared with the historical experience, peaking (as noted) at nearly $10 \%$ of total fiscal revenues, or $3.7 \%$ of GDP, in 1984 . This would have led to negative consequences for GDP growth, although this would have been mitigated to some extent owing to the reduced volatility of government tax revenues. As Figure 3 shows, however, from 1988 onward the returns from the fund would have exceeded resource revenues in most years. The counterfactual over this period would have been government enjoying higher and less volatile total revenues than it enjoyed historically, with positive consequences for GDP growth. These effects of a SWF on government revenues would therefore be countervailing over the years prior to and following 1988. The choice to invest in a fund would have continuously strengthened the public sector balance sheet relative to the historical experience, while at the same time buffering the public finances from the effects of resource price volatility. It is worth recalling the arguments in IMF (2018), whereby a stronger public sector balance sheet has positive impacts on the cost of debt and may lead to quicker recoveries from recessions.

Focusing on the public sector balance sheet, Figure 5 plots the net worth of general government from 1995 to 2018. The starting point for this is ONS (various) which now publishes the general government balance sheet annually, with the series beginning in $1995 .{ }^{17}$ The accounts do not include the value of natural resources other than land. Figure 5 measures public sector net worth including North Sea oil and gas, building on the resource accounts presented in Section 2. The value of the simulated SWF is also included in Figure 5, providing a measure of the potential public sector net worth if government had decided to implement such a fund. Note, however, that in a counterfactual world where the UK did implement a SWF, the estimates of general government net worth could differ from what is shown in Figure 5 because, as discussed above, total general government tax revenues would differ from the historical figures over the life of the SWF (see Figure 3), with the result that public sector investments in land and produced assets would also be expected to differ from their historical values.

\footnotetext{
${ }^{17}$ These ONS data differ from the data in IMF (2018) as the latter includes the assets and liabilities of those financial corporations which remain publicly owned (in the wake of the financial crisis post-2008) and provides a fuller assessment of the pension liabilities for public employees.
} 


\section{Figure 5: UK General Government Net Worth 1995-2018 (\% of GDP)}

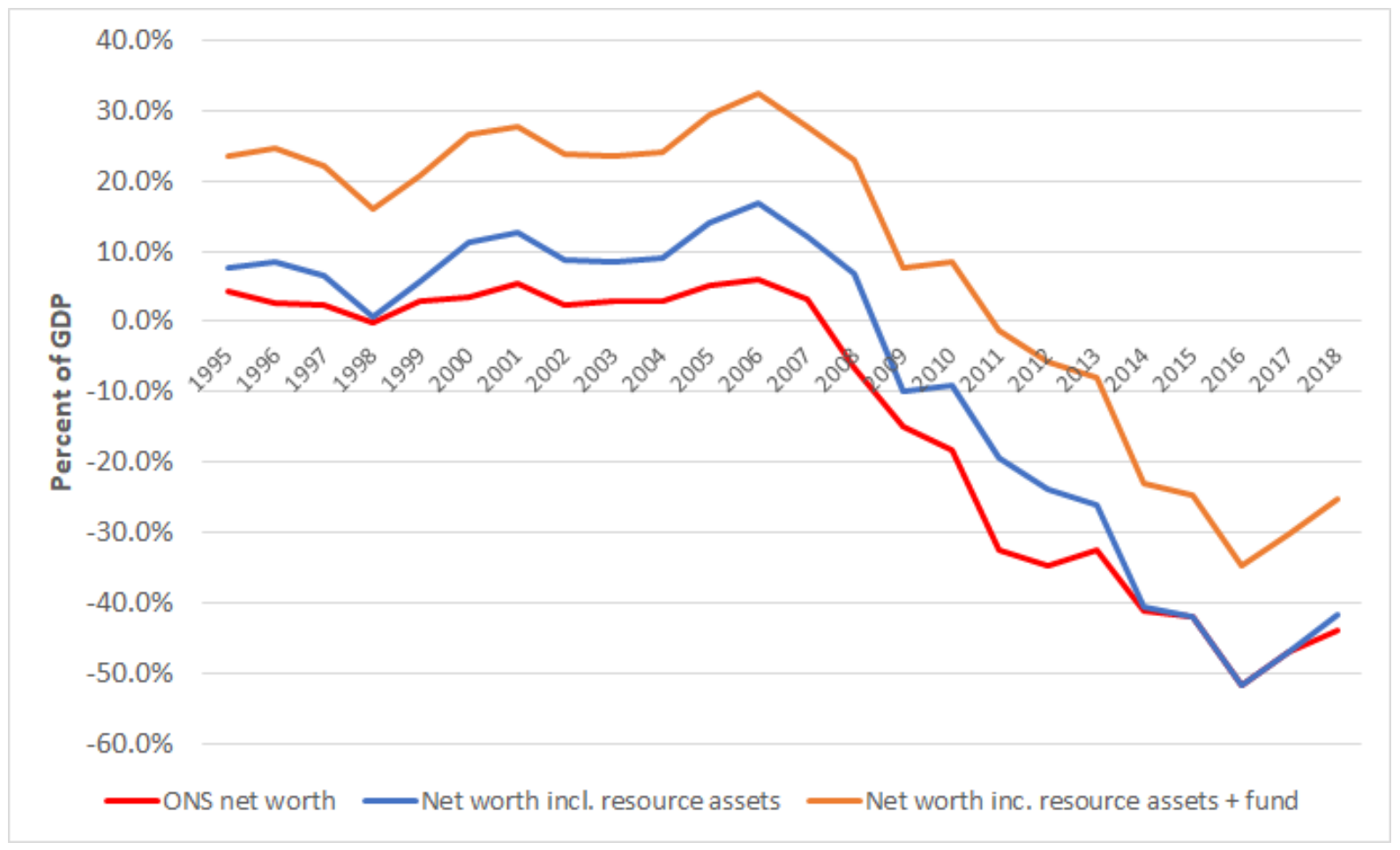

Source: ONS (various), OBR (various) and authors' calculations.

Note: 'fund' refers to our simulated (bird-in-hand) SWF

Figure 5 shows that in 2006, just before the financial crisis, including petroleum assets as well as the simulated SWF boosts general government net worth from $6 \%$ of GDP (the published figure) to $32 \%$ of GDP. All three measures of net worth plunge in tandem starting in 2007. But by 2018 the broadest measure of public sector net worth reached $-25 \%$ of GDP, versus the historical figure of $-44 \%$ of GDP as published by ONS. The value of the simulated SWF averages close to $17 \%$ of GDP over the whole period 1995-2018. As a result, this broadest measure of public sector is positive, on average, over the period ( $9 \%$ of GDP), whereas it is negative on average for the other two net worth metrics in the figure.

As seen in Figure 5, government borrowing jumped sharply in response to the financial crisis. If a SWF were operational at this point, the clear priority for government would be fiscal and monetary stimulus, rather than continued payments into the fund. Indeed, data for Norway show that payments into the Government Pension Fund declined by $60 \%$ over 2008-2010, followed by minor capital withdrawals in 2016-2017 and renewed payments into the fund in 
2018. ${ }^{18}$ Beyond the immediate crisis, the policy challenge for any government would be determining when to return to regular payments into the SWF.

More generally, our analysis of a simulated SWF for the UK has noted the many uncertainties in the estimated value of the fund and its financial returns, including the lack of a counterfactual effect on the public finances that would entail if all resource revenues had been invested in the fund starting in 1975. The lack of annual data on returns to global financial assets is also an important limitation. But the simulation suggests that the UK government could be on significantly stronger grounds, as measured by the public sector balance sheet, in 2018 compared with the historical experience.

Finally, it is important to note that choosing to establish a SWF in 1975 would have had general equilibrium effects on the economy, given the size of the petroleum revenues that would have been invested in the fund rather than paid into the fiscus (3.7\% of GDP in 1984). GDP would not only have been lower prior to 1988 and higher thereafter, but its composition would have changed as prices and quantities adjusted across multiple markets. An overarching effect of implementing the SWF would have been reductions in Dutch Disease as a result of investing the revenues in foreign financial assets, with consequent general equilibrium effects on the trade balance.

\subsection{Looking Forward - Conventional and Unconventional Gas and Oil Resources}

While the preceding historical simulation of a SWF has intrinsic interest, our framework has implications for the future as well. That is, if the UK were to start a fund 'now' in order channel revenues from remaining petroleum reserves, how might this compare with the missed opportunity of the SWF that we have simulated? Developing an illustrative model of a future SWF for petroleum resources is therefore another of our key objectives in this paper.

In this respect, UK petroleum reserves remain substantial. OGA (2019c) indicate that closing stocks of proven and probable reserves of UK oil and gas in 2018 while sizable correspond (in tonnes of oil equivalent) to under $13 \%$ of cumulative production over the period 1975 -

${ }^{18}$ Statistics Norway (2019) 
2018. Broader definitions of reserves change this picture considerably, of course. ${ }^{19}$ But a reasonable presumption might be that a SWF for North Sea petroleum resources started 'now' would be small compared to the missed opportunity of a past fund, in the absence of relatively optimistic forecasts about resource prices and the extent of reserves.

The foregoing refers to conventional resources. A potential SWF has been discussed relatively recently within UK policy processes for unconventional resources (see, for example, HM Treasury, 2013, 2017): most notably to natural gas or oil resources trapped in shale beds - formed of sedimentary rocks. These can be freed by hydraulic fracturing (or 'fracking') entailing injection of fluids, including water, at high pressure into these rocks (Royal Society/ Royal Academy of Engineers, 2012). Significant attention has centred on shale gas production in the US using this technology, its transformative effect on the gas market, as well as the institutional reasons for this boom (see, for example: Rogers, 2011; Wang and Krupnick, 2013). Debate has also focused on the range of negative externalities such as damage from water pollution and seismicity (see, for example, Krupnick et al. 2013; Royal Society/ Royal Academy of Engineers, 2012; Mason et al. 2015) ${ }^{20}$ Indeed, such considerations have framed a lot of the surrounding political debate and as recently as November 2019, the UK Government announced a new moratorium on fracking. ${ }^{21}$

In what follows, however, we ask an 'in principle' question about the potential magnitude of a UK fund based on unconventional resource revenues. This is not straightforward. Notably, as indicated in Table A1.3 in Annex 1, available data for these physical resources are broad definitions of resource extent and do not indicate resources which might ultimately be economically recoverable (given prices, costs and so on). Hilaire et al. (2015) and Saussay (2018) respectively estimate this across continental Europe and globally by combining detailed US data in conjunction with less fine-grained geological data that exist outside of the US where resource production is limited or has not yet begun. However, these extrapolations are not applicable to the UK specifically. Sandrea and Sandrea (2014) and Sandrea and Peels

\footnotetext{
19 This would include contingent resources (defined as known resources which are potentially recoverable in a technical sense) and prospective (i.e. undiscovered) resources, whether mapped or as yet unmapped (OGA, 2019a).

${ }^{20}$ Cotton et al. (2014) discuss one further but related obstacle which is the way in which perceptions of local costs versus wider benefits frames how those living in the vicinity of possibly rich deposits perceive the fairness of proposals to drill exploratory wells.

${ }^{21}$ This, on of the face of it, was based largely on concerns about seismicity (see, for example, Financial Times, $2^{\text {nd }}$ November, https://www.ft.com/content/35591716-fcc5-11e9-a354-36acbbb0d9b6 [Accessed 15/11/19]
} 
(2014) estimate actual recovery factors - in effect, economically recoverable resources - as a proportion of gas-in-place across a wide range of deposits in the US. These range from 1.7\% to $11.2 \%$ with Sandrea and Peels (2014) estimating an average recovery factor of 5.4\%. US EIA (2013) stresses the geological complexity of extracting UK shale resources compared to the US experience. Indeed, the relationship between technical recoverability and gas-in-place in Table A1.3 (from US EIA, 2015) is around 4\%. Speculating on the size of a potential UK fund based on unconventional resources obviously then requires caution. We do so here, however, to gain some sense of the circumstances in which this fund might approach in magnitude the apparent missed opportunity of the past, as suggested by our simulated fund for conventional resources from 1975-2018.

Table 1: Hypothetical values of a SWF for UK Shale Resources (2018, GBP millions)

\begin{tabular}{|c|c|c|c|c|c|}
\hline & & & & source ext & \\
\hline & & & Low & Medium & High \\
\hline & & Median & 20,691 & 33,829 & 58,408 \\
\hline & डे & Min. & 5,542 & 9,061 & 15,645 \\
\hline 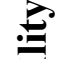 & $\checkmark$ & Max. & 62,072 & 101,487 & 175,224 \\
\hline 를 & & Median & 51,726 & 84,572 & 146,020 \\
\hline 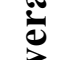 & ปี่ & Min. & 13,855 & 22,653 & 39,113 \\
\hline है & $z$ & Max. & 155,179 & 253,717 & 438,061 \\
\hline $\mathscr{\mathscr { U }}$ & & Median & 82,762 & 135,316 & 233,633 \\
\hline & 80 & Min. & 22,168 & 36,245 & 62,580 \\
\hline & $\approx$ & Max. & 248,286 & 405,947 & 700,898 \\
\hline
\end{tabular}

Source: authors' calculations based on data and assumptions in Table A1.4 in Annex 1.

Table 1 illustrates some findings from simulations based on all combinations of our assumptions (Table A1.4 in Annex 1). As the key parameters are resource extent and recoverability, the table organises these summary findings according to 'low', 'medium' and 'high' for each of these parameters. The specific values in the Table describe the median fund size and the minimum/ maximum fund size (e.g. given assumed resource extent/ recoverability as well as other assumptions about price, rents and revenue capture). Again it is important to acknowledge the tentative character of these estimates. Moreover, we do not consider the environmental and regulatory hurdles (KPMG, 2011) that will determine the value of these resources as economic assets. Nor do these estimates speak to the timing of a fund accruing, as we have not assumed a further (arbitrary) depletion path.

Nevertheless, what seems reasonably clear is that this (hypothetical) simulated future fund is comparable in size to our simulated fund for conventional resources only if relatively high levels of resource extent apply. Of course, the probability assessments in Andrews (2014, 
2013), Monaghan (2014) and Greenhalgh (2016), and summarised in Table 1, imply that these magnitudes are far less likely to be exceeded. A more conservative approach might therefore focus mostly on lower estimates of resources extent. For median magnitudes of resource extent - i.e. those which have a $50 \%$ probability of being exceeded - an implied (future) fund starts to approach our $£ 354$ billion threshold value only if recoverability along with values for other parameters are relatively high. Not surprisingly, for low values of resource extent the reckoned future fund is correspondingly smaller even when combined with relatively optimistic values for other parameters. While these magnitudes cannot be said to be trivial, arguably these do underline the missed opportunity of the fund based on conventional resources from 1975-2018.

\section{Conclusions and Policy Implications}

Our simulated sovereign wealth fund (SWF) suggests that, had the UK established such a fund along the lines of the Norwegian example starting in 1975, its value would amount to about GBP 354 billion in 2018. We argue that the SWF would have provided a number of additional benefits. First, there would be much lower volatility of payouts from the fund compared with the volatility of resource revenues; this would have consequences for fiscal stability. Second, owing to the early 1980's boom in oil prices, the fund would have fairly rapidly produced annual income greater than annual resource revenues. ${ }^{22}$ Finally, the UK government would today enjoy a rough doubling of the public sector balance sheet, and the balance sheet would be more diversified. This latter point is perhaps the most important, as IMF (2018) suggests: a stronger public sector balance sheet can yield important fiscal benefits.

The analysis of resource asset accounts for the UK suggests that these accounts provide valuable information that, if included in the public sector balance sheet, could strengthen the published figures for net worth and send a signal to the markets for UK debt. We show that the sum of current resource wealth and the simulated SWF increases public sector net worth by $24 \%$ of GDP by 2006 , compared to the figures published by ONS. As we have noted at several points, our simulation of a UK SWF does not include a counterfactual path for public spending in the presence of a SWF, largely because we feel such a counterfactual would be

\footnotetext{
${ }^{22}$ This boom, of course, could not have been foreseen by decision-makers in 1975 .
} 
arbitrary. But we have also noted that investing resource revenues in the fund from 1975 to 1988 would have entailed a tightening of public finances, with consequences for GDP growth. After 1988 the constraints on public finance could have been looser because the fund simulation shows that payouts from the fund would have exceeded resource revenues in 1988 and beyond. Because we assume that the fund would be invested in foreign assets, there also would have been counterfactual impacts on the Sterling exchange rate as well, potentially lowering Dutch Disease effects.

Over the long period this analysis covers, a key decision not to establish a SWF was made in 1979. Government considered the question of sustainability and rejected it. Hughes (2014) has questioned the value of a formal SWF in a large, diverse economy with relatively small petroleum resources. He suggests that the resource rents should indeed be reinvested in other forms of capital, but that it is sufficient to monitor indicators such as depletion-adjusted net saving to track the extent to which this is happening. Our analysis of asset accounts for the UK, however, suggests that depletion-adjusted net saving has been quite low since 1975 (averaging just under 5\% of GDP, with dips below 0 in the 2000 s), which would be consistent with weak investment of resource revenues.

Based on our analysis, it is at least arguable that the discipline imposed by establishing a SWF could have generated greater benefits from the North Sea petroleum windfall than were actually realised in the UK. Of course, this is now water under the bridge as far as practical policy is concerned. It is perhaps surprising though that only recently, in the context of the pros and cons of developing the UK's shale oil and gas resources, has the issue has been raised again. However, our speculative assessment in this paper is that barring propitious assumptions about physical extent and the economic value of depletion, any fund - based on remaining conventional and unconventional resources - while not insubstantial is unlikely to approach the magnitude of the SWF that we simulate over the period 1975-2018.

Our analysis has focused on the benefits to the UK that could have resulted from establishing a SWF for the exploitation of North Sea petroleum resources. But the context for future exploitation of petroleum has changed as the world takes stock of climate damages from greenhouse gas (GHG) emissions. The fact that the UK is a signatory to the Paris Agreement on Climate Change is part of this changing context. If the UK were to develop shale resources and establish a SWF, the inclusion of global climate damages as part of the 
economic analysis for such a project would provide valuable transparency. But it would not necessarily answer the overarching question of the future role that petroleum resources will play in a changing climate, as well as related decisions about investing the proceeds of petroleum extraction in climate-friendly financial assets. 


\section{References}

Abdo, H., 2014. Investigating the effectiveness of different forms of mineral resources governance in meeting the objectives of the UK petroleum fiscal regime, Energy Policy, 65, 48-56.

Abdo, H., 2010. The taxation of UK oil and gas production: why the windfalls got away, Energy Policy, 38, 5625-5635.

Abdo, H., Mangena, M., Needham, G., Hunt, D., 2018. Disclosure of provisions for decommissioning costs in annual reports of oil and gas companies: a content analysis and stakeholder views, Account. Forum, 42, 341-358.

Andrews, I.J., 2014. The Jurassic shales of the Weald Basin, geology and shale oil and shale gas resource estimation, British Geological Survey and Department of Energy and Climate Change, London.

Andrews, I.J., 2013. The Carboniferous Bowland shale gas study, geology and resource estimation, British Geological Survey and Department of Energy and Climate Change, London.

Asheim, G.B., Weitzman, M.L., 2001. Does NNP growth indicate welfare improvement?, Econ. Lett., 73, 233-239.

Atkinson, A.B., 2016. Inequality: What Can be Done?, Harvard University Press, Cambridge, Mass.

Barclays, 2013. Equity Gilt Study 2013, Barclays, London.

BoE (Bank of England), 1980. The North Sea and the United Kingdom economy: some longer-term perspectives and implications, Bank of England Q. Bull., Dec. 1980, 449-454.

BoE (Bank of England), 1982. North Sea oil and gas: costs and benefits, Bank of England Q. Bull., March 1982, 56-73.

BoE (Bank of England), 1986. North Sea oil and gas, Bank of England Q. Bull., Dec. 1986, $510-518$

Bean, C., 1987. The Impact of North Sea Oil, in Dornbusch, R. and Layard, R. eds.. The Performance of the British Economy, Clarendon Press, Oxford.

BEIS (UK Department for Business, Energy and Industrial Strategy). 2017. BEIS 2017 Fossil Fuel Price Assumptions, BEIS, London.

Clark, G.L., Dixon, A.D., Monk, A.H.B., 2013. Sovereign Wealth Funds, Legitimacy, Governance and Global Power, Princeton University Press, New Jersey.

Credit Suisse., 2019. Global Investment Returns Yearbook 2019, Credit Suisse Research Institute, Zurich. 
Credit Suisse., 2011. Global Investment Returns Yearbook 2011, Credit Suisse Research Institute, Zurich.

Cummine, A., 2016. Citizens' Wealth, Why and How. Sovereign Wealth Funds Should Be Managed for the People by the People, Yale University Press, New Haven and London.

Damodoran, A., 2014. http,//www.stern.nyu.edu/ adamodar/pc/datasets/histretSP.xls, accessed Dec. 12, 2014.

Dasgupta, P., Mäler, K.-G., 2000. Net national product, wealth and social welfare, Environ. and Development Econ., 51, 69-93.

Detter, D., Fölster. S.,2015. The Public Wealth of Nations. Macmillan, Basingstoke.

Dimson, E., Marsh, P.R., Staunton, M., 2002. Triumph of the Optimists, 101 Years of Global Investment Returns, Princeton University Press, New York.

Erdös, P., 2012. Have oil and gas prices got separated?, Energy Policy, 49, 707-718.

Greenhalgh, E., 2016. The Jurassic Shales of the Wessex Area, Geology and Shale Oil and Shale Gas Resource Estimation, British Geological Survey for the Oil and Gas Authority, London.

Gruber, J.W., Kamin, S.B., 2012. Fiscal positions and government bond yields in OECD countries. J. of Money, Credit, and Bank., 44(8), 1563-87.

Hadzi-Vaskov, M., Ricci L.A., 2016. Does gross or net debt matter more for emerging market spreads? IMF Working Paper 16/246, International Monetary Fund, Washington DC

Henao-Arbelaez, C., Sobrinho. N., 2017. Government financial assets and debt sustainability. IMF Working Paper 17/173, International Monetary Fund, Washington DC.

Hamilton, K., 2016. Measuring sustainability in the UN system of environmental and economic accounting, Environ. and Resour. Econ., 641, 25-36.

Hamilton, K., Atkinson, G., 2013. Resource discoveries, learning, and national income accounting, World Bank Policy Research Working Paper No. 6505, World Bank, Washington DC.

Hamilton, K., Atkinson, G., 1996. Green accounts and air pollution, Energy Policy, 24, 67584.

Hamilton, K., Clemens, M., 1999. Genuine savings rates in developing countries, World Bank Econ. Rev., 13, 333-356.

Hamilton, K., Hartwick, J.M., 2014. Wealth and sustainability, Oxford Rev. of Econ Policy, 301, 170-187.

Hamilton, K., Withagen, C.A.A.M., 2007. Savings, growth and path of utility, Canadian J. of Econ., 402, 703-713. 
Hamilton, K., Ley, E., 2013. Sustainable fiscal policy for mineral based economies, in: Amadou, S., Rabah, A., Gylfason, B. (Eds.), Beyond the Curse, Policies to Harness the Power of Natural Resources, International Monetary Fund, Washington DC.

Hartwick, J.M., 1977. Intergenerational equity and the investment of rents from exhaustible resources, American Econ. Rev., 67, 972-74.

Hassler, J., Krusell, P., Shifa, A., Spiro, D. 2015. Sovereign wealth funds and spending constraints in resource rich developing countries: the case of Uganda, Institute for International Economic Studies, Stockholm University.

Hawksworth, P., 2008. Dude, Where's my oil money gone?, PriceWaterhouseCoopers, London.

Hilaire, J., Bauer, N., Brecha, R.J., 2015. Boom or bust? Mapping out the unknowns of global shale gas production potential, Energy Econ., 49, 581-587.

HMRC (Her Majesty's Revenue and Customs), 2013. Statistics of Government Revenues from UK Oil and Gas Production, HMRC, London.

HMRC (Her Majesty's Revenue and Customs), 2008. A Guide to UK and UK Continental Shelf, Oil and Gas Taxation, HMRC, London.

HM Treasury, 2018. The Green Book, Appraisal and Evaluation in Central Government, HM Treasury, London.

HM Treasury, 2017. Shale Wealth Fund, Response to the Consultation, HM Treasury, London.

HM Treasury, 2013. Harnessing the Potential of the UK's Natural Resources, A Fiscal Regime for Shale Gas, Open Consultation, HM Treasury, London.

Hughes, G., 2014. The energy sector in Scotland's future, Oxford Rev. of Econ. Policy, 302, 374-391.

IMF (International Monetary Fund), 2018. Fiscal Monitor August 2018, International Monetary Fund, Washington DC.

Khan, J., Greene, P., Wei Hoo, K., 2013. Monetary Valuation of UK Continental Shelf Oil \& Gas Reserves, Office for National Statistics, London.

Kemp, A., 2011a. The Official History of North Sea Oil and Gas, Volume I: The Growing Dominance of the State, Government Official History Series, Routledge, London.

Kemp, A., 2011b. The Official History of North Sea Oil and Gas, Volume II: Moderating the State's Role, Government Official History Series, Routledge, London.

KPMG, 2011. Shale Gas: A Global Perspective, KPMG Global Energy Institute, KPMG International, London. 
Krupnick, A.J., 2013. Managing the Risks of Shale Gas, Key Findings and Further Research, Resources for the Future, Washington DC.

Krupnick, A.J., Gordon, H., Olmstead, S., 2013. Pathways to dialogue, what the experts say about the environmental risks of shale gas development, RFF Report, Resources for the Future, Washington DC.

Mason, C.F., Muehlenbachs, L.A., Olmstead, S.M., 2015. The economics of shale gas development, RFF Discussion Paper 14-42 Revised version, Resources for the Future, Washington DC.

Martinez-Oviedo, R., Medda, F., 2017. Assessing the effects of adding timberland and farmland into resource-based sovereign wealth fund portfolios, J. of Econ. and Bus., 91, 2440.

Monaghan, A.A., 2014. The Carboniferous Shale of the Midland Valley of Scotland, Geology and Resource Estimation, British Geological Survey and Department of Energy and Climate Change, London.

Nakhle, C., 2008. Petroleum Taxation, Routledge, Abingdon.

NAO (National Audit Office), 2019. Oil and Gas in the UK: Offshore Decommissioning, National Audit Office, London.

OBR (Office for Budgetary Responsibility), Various years. Fiscal Sustainability Report, Office for Budgetary Responsibility, London.

Obst, C., Vardon, M., 2014. Recording environmental assets in the national accounts, Oxford Rev. of Econ. Policy, 301, 126-144.

Odling-Smee, J., Riley, C., 1985. Approaches to the PSBR, National Institute Economic Review, August 1985.

OGA (Oil and Gas Authority), 2019a. Income from and Expenditure on UKCS Exploration, Development and Operating Activities: 1970 to 2018, Oil and Gas Authority, Aberdeen.

OGA "Oil and Gas Authority), 2019b. UKCS Decommissioning: 2019 Cost Estimate Report, Oil and Gas Authority, Aberdeen.

OGA (Oil and Gas Authority), 2019c. UK Oil and Gas Reserves and Resources as of end 2018, Oil and Gas Authority, Aberdeen.

ONS (Office for National Statistics), Various years. UK National Accounts The Blue Book, ONS, London.

Ossowski, R., Villafuerte, M., Medas, P., Thomas, T., 2008. The Role of Fiscal Institutions in Managing the Oil Revenue Boom, International Monetary Fund, Washington DC. 
Ossowski, R., Halland, H., 2017. The Economics of Sovereign Wealth Funds, in Hamilton, K., Hepburn, C., (Eds.), National Wealth, What is missing, why it matters. Oxford University Press, Oxford.

Pearce, D.W., Atkinson, G., 1993. Capital theory and the measurement of sustainable development: an indicator of 'weak' sustainability, Ecological Economics, 82, 103-108.

Rogers, H., 2011. Shale gas: the unfolding story, Oxford Rev. of Econ. Policy, 271, 117-143.

Royal Society/ Royal Academy of Engineering, 2012. Shale Gas Extraction in the UK, A Review of Hydraulic Fracturing, Royal Society/ Royal Academy of Engineering, London.

Rutledge, I., Wright, P., 1998. Profitability and taxation in the UKCS oil and gas industry, analysing the distribution of rewards between company and country, Energy Policy, 2610, 795-812.

Sandrea, R., Sandrea, I., 2014. New well-productivity data provide us shale potential insights, Oil \& Gas J., 11211, 66.

Sandrea, R., Peels, G., 2014. Algorithm provides new EUR estimates for US shale plays, Oil \& Gas J., 1128, 56.

Saussay, A., 2018. Can the US shale revolution be duplicated in Continental Europe? An economic analysis of European shale gas resources, Energy Econ., 69, 295-306.

Scottish Government, 2009. An Oil Fund for Scotland, Taking Forward Our National Conversation, The Scottish Government, Edinburgh.

Segal, P., 2012. How to spend it, resource wealth and the distribution of resource rents, Energy Policy, 51, 340-348.

Statistics Norway, 2019. StatBank, https,/www.ssb.no/en/statbank accessed 06/01/2020.

UN (United Nations) 2013. System of Environmental-Economic Accounts, Central Framework, United Nations, New York.

US EIA (United States Energy Information Administration), 2018. U.S. Crude Oil and Natural Gas Proved Reserves, Year-end 2016, US Department of Energy, Washington DC.

US EIA (United States Energy Information Administration), 2013. Technically Recoverable Shale Oil and Shale Gas Resources, An Assessment of 137 Shale Formations in 41 Countries Outside the United States, US Department of Energy, Washington DC.

Van der Ploeg, R., 2014. Guidelines for exploiting natural resource wealth, Oxford Rev. of Econ. Policy, 301, 145-169.

Wang, Z., Krupnick, A.J., 2013. A Retrospective Review of Shale Gas Development in the United States, What Led to the Boom?, RFF Discussion Paper 13-12, Resources for the Future, Washington DC. 
Annex 1: Data and assumptions

Table A1.1: Assumptions and Parameter Choices for Petroleum Asset Accounts

\begin{tabular}{l|l}
\hline Assumption or parameter & Value \\
\hline Resource lifetime & $\begin{array}{l}\text { Proven plus probable reserves divided by current } \\
\text { production rates }\end{array}$ \\
\hline Path of resource rents & $\begin{array}{l}\text { Fixed at the current year and held constant up to the } \\
\text { point of exhaustion }\end{array}$ \\
\hline Co-production & $\begin{array}{l}\text { For accounting purposes gas is treated as a co-product } \\
\text { of oil extraction }\end{array}$ \\
\hline $\begin{array}{l}\text { Opportunity cost of fixed capital } \\
\text { (assumed rate of return on assets) }\end{array}$ & $4.3 \%$ \\
\hline Discount rate & $3.5 \%$ \\
\hline
\end{tabular}


Table A1.2: Monetary Asset Account for UK Oil \& Gas, 1975-2018 (2018, million GBP)

\begin{tabular}{|c|c|c|c|c|c|}
\hline \multirow[b]{2}{*}{1975} & \multirow{2}{*}{$\begin{array}{l}\text { Asset value } \\
\ldots\end{array}$} & \multirow{2}{*}{$\begin{array}{r}\text { Production value } \\
1,842\end{array}$} & \multirow{2}{*}{$\begin{array}{r}\text { Resource rent } \\
\ldots\end{array}$} & \multicolumn{2}{|c|}{ Depletion value (\% of res. rent) } \\
\hline & & & & $\cdots$ & $\ldots$ \\
\hline 1976 & $\ldots$ & 5,111 & $\cdots$ & $\ldots$ & ... \\
\hline 1977 & 135,716 & 12,561 & 5,194 & 2,171 & $41.8 \%$ \\
\hline 1978 & 129,673 & 15,028 & 5,663 & 2,996 & $52.9 \%$ \\
\hline 1979 & 505,407 & 37,697 & 26,930 & 17,268 & $64.1 \%$ \\
\hline 1980 & 423,335 & 35,011 & 23,370 & 15,359 & $65.7 \%$ \\
\hline 1981 & 428,133 & 38,767 & 25,845 & 17,931 & $69.4 \%$ \\
\hline 1982 & 452,898 & 45,179 & 31,041 & 22,912 & $73.8 \%$ \\
\hline 1983 & 452,658 & 49,900 & 34,859 & 26,930 & $77.3 \%$ \\
\hline 1984 & 483,223 & 57,698 & 41,765 & 33,491 & $80.2 \%$ \\
\hline 1985 & 399,055 & 54,430 & 36,932 & 30,189 & $81.7 \%$ \\
\hline 1986 & 97,015 & 26,689 & 9,500 & 7,878 & $82.9 \%$ \\
\hline 1987 & 102,719 & 27,108 & 10,496 & 8,792 & $83.8 \%$ \\
\hline 1988 & 37,615 & 19,725 & 3,886 & 3,263 & $84.0 \%$ \\
\hline 1989 & 34,455 & 19,003 & 3,223 & 2,642 & $82.0 \%$ \\
\hline 1990 & 40,728 & 20,213 & 3,822 & 3,136 & $82.0 \%$ \\
\hline 1991 & 14,492 & 18,345 & 1,307 & 1,060 & $81.2 \%$ \\
\hline 1992 & 3,384 & 17,766 & 291 & 233 & $80.1 \%$ \\
\hline 1993 & 15,554 & 19,611 & 1,372 & 1,107 & $80.7 \%$ \\
\hline 1994 & 32,066 & 21,675 & 3,256 & 2,724 & $83.7 \%$ \\
\hline 1995 & 42,857 & 22,852 & 4,766 & 4,067 & $85.3 \%$ \\
\hline 1996 & 79,933 & 26,800 & 8,971 & 7,669 & $85.5 \%$ \\
\hline 1997 & 59,222 & 24,310 & 6,424 & 5,454 & $84.9 \%$ \\
\hline 1998 & 13,607 & 19,422 & 1,654 & 1,436 & $86.8 \%$ \\
\hline 1999 & 40,665 & 23,215 & 5,609 & 4,974 & $88.7 \%$ \\
\hline 2000 & 122,367 & 34,182 & 17,170 & 15,266 & $88.9 \%$ \\
\hline 2001 & 114,935 & 32,222 & 15,876 & 14,081 & $88.7 \%$ \\
\hline 2002 & 105,497 & 31,140 & 14,940 & 13,302 & $89.0 \%$ \\
\hline 2003 & 94,926 & 28,797 & 13,221 & 11,741 & $88.8 \%$ \\
\hline 2004 & 104,686 & 29,119 & 13,838 & 12,188 & $88.1 \%$ \\
\hline 2005 & 162,791 & 34,991 & 19,573 & 16,957 & $86.6 \%$ \\
\hline 2006 & 198,726 & 38,789 & 22,937 & 19,719 & $86.0 \%$ \\
\hline 2007 & 166,710 & 35,541 & 19,160 & 16,457 & $85.9 \%$ \\
\hline 2008 & 249,747 & 44,977 & 27,437 & 23,353 & $85.1 \%$ \\
\hline 2009 & 94,684 & 27,738 & 9,935 & 8,373 & $84.3 \%$ \\
\hline 2010 & 168,121 & 34,881 & 16,900 & 14,103 & $83.5 \%$ \\
\hline 2011 & 245,832 & 38,721 & 20,463 & 16,222 & $79.3 \%$ \\
\hline 2012 & 206,676 & 35,143 & 15,126 & 11,468 & $75.8 \%$ \\
\hline 2013 & 126,046 & 31,783 & 9,162 & 6,927 & $75.6 \%$ \\
\hline 2014 & 9,242 & 26,119 & 680 & 516 & $76.0 \%$ \\
\hline 2015 & $\cdots$ & 21,138 & $\cdots$ & $\ldots$ & $\ldots$ \\
\hline 2016 & $\ldots$ & 18,250 & $\cdots$ & $\cdots$ & .. \\
\hline 2017 & $\ldots$ & 22,470 & $\ldots$ & $\ldots$ & $\ldots$ \\
\hline 2018 & 46,599 & 28,238 & 5,441 & 4,688 & $86.2 \%$ \\
\hline
\end{tabular}

Notes: “...” indicates negligible or negative values. 
Table A1.3: Estimates of Potential Shale Resources in the UK (mtoe) ${ }^{[a]}$

\begin{tabular}{llccc}
\hline Study & Area of assessment & Shale Gas & Shale Oil & Total \\
\hline Monaghan (2014) & Midland Valley, & $1,260(p 90)$ & $421(p 90)$ & $1681(p 90)$ \\
& Scotland & $2,043(p 50)$ & $793(p 50)$ & $2,836(p 50)$ \\
& & $3,429(p 10)$ & $1,497(p 10)$ & $4,926(p 10)$ \\
\hline Andrews (2013) & Bowland, Northern & $20,880(p 90)$ & & $20,880(p 90)$ \\
& England & $33,930(p 50)$ & & $33,930(p 50)$ \\
& & $58,140(p 10)$ & & $57,140(p 10)$ \\
Andrews (2014) & & $293(p 90)$ & $293(p 90)$ \\
& Weald Basin, & & $591(p 50)$ & $591(p 50)$ \\
& Southern England & & $1,143(p 10)$ & $1,143(p 10)$ \\
Greenhalgh (2016) & Wessex, Southern & & $32(p 90)$ & $32(p 90)$ \\
& England & & $149(p 50)$ & $149(p 50)$ \\
& & $378(p 10)$ & $378(p 10)$ \\
\hline EIA (2015) & Whole of UK & 16,033 & 7,288 & 23,320 \\
& & $648^{[b]}$ & $94^{[b]}$ & $742^{[b]}$ \\
\hline
\end{tabular}

Notes:

[a] Estimates refer to total resources-in-place unless otherwise indicated, where $p(90)$ refers to $90 \%$ probability of these estimated resources being exceeded, $p(50)$ refers to $50 \%$ probability of these estimated resources being exceeded and $p(10)$ refers to a $10 \%$ probability of these estimated resources being exceeded. Taken as a whole, these data indicate resource extent is roughly 23,000 mtoe with a $90 \%$ probability, and at least 37,000 mtoe and 63,000 mtoe with 50\% and $10 \%$ probabilities respectively.

[b] Estimates refer to technically recoverable resources.

Table A1.4: Assumptions and Parameter Choices for Simulated Fund for Unconventional Gas and Oil

\begin{tabular}{llrrr}
\hline \multirow{2}{*}{ Parameter } & \multirow{2}{*}{ Resource } & \multicolumn{3}{c}{ Assumed value } \\
\cline { 3 - 5 } & & Low & Central & \multicolumn{1}{c}{ High } \\
\hline Resources-in-place & Gas (therms) & 8,856 & 14,323 & 24,551 \\
& Oil (million tonnes) & 761 & 1,558 & 3,049 \\
\hline & & & & \\
\hline $\begin{array}{l}\text { Proportion of resources in place which are } \\
\text { economically recoverable }\end{array}$ & Gas & 0.02 & 0.05 & 0.08 \\
& & & & \\
\hline Price & Oil & 0.01 & 0.025 & 0.04 \\
\hline Rent as a proportion of production value & Gas (p/therm) & 30 & 50 & 70 \\
\hline Revenue capture as a proportion of total rent Gas/ oil & 300 & 500 & 700 \\
\hline
\end{tabular}

Source: Table A1.3 and authors' calculations. BEIS (2017) 


\section{Annex 2: Volatility and a simulated SWF}

In this annex we simulate a SWF for the UK that invests only in US financial assets, yielding results that are in some respects more realistic than those calculated in the main body of the paper. The analysis builds upon historical data on nominal returns on US financial assets going back to 1928 (reported in Damodaran 2014), as well as historical inflation data from the US Bureau of Labor Statistics. We simulate two funds that invest in a portfolio of $60 \%$ S\&P 500 equities and 40\% 10 year bonds. The first uses the historical annual returns for such a portfolio, based on data from Damadoran (2014). The second simulates smoothed returns using the methods applied to the SWF of the main text, with a long-run (1928-2013) real rate of return of $4.6 \%$ for the $60-40$ portfolio, again based on the Damadoran (2014) data.

Figure A2.1: UK SWF Invested in US Financial Assets, Smoothed and Unsmoothed, \$mn (nominal), 1975-2010

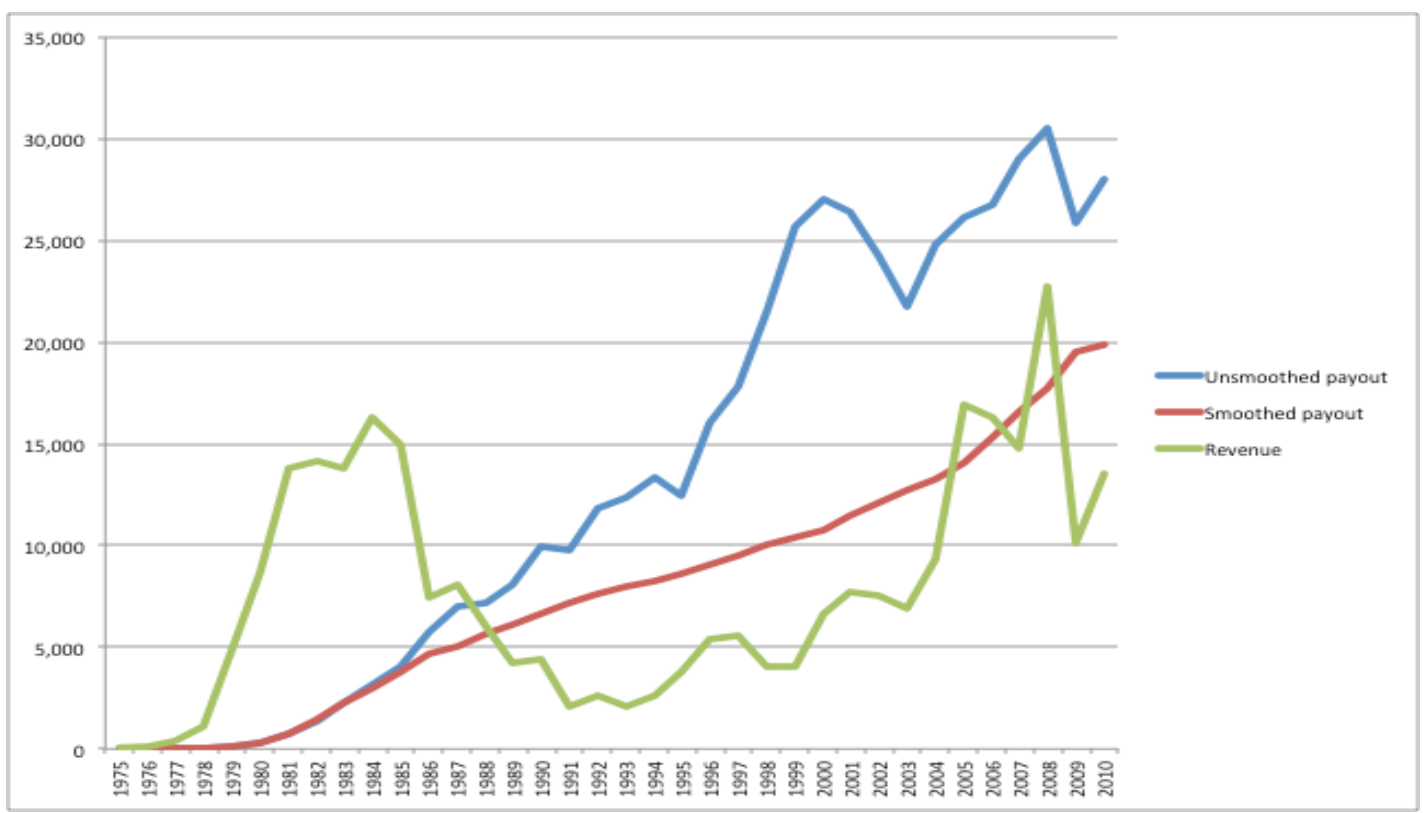

Source: authors' calculations

Figure A2.1 plots resource revenues and payouts from the unsmoothed and smoothed funds in nominal dollars from 1975 to 2010. As expected, the curves for resource revenues and the smoothed fund bear a family resemblance to the equivalent curves in Figure 3, with the key difference being nominal dollars vs. constant 2010 GBP. By 2010 the unsmoothed fund using historical nominal returns is nearly 50\% larger than the smoothed fund (reflecting high 
returns on financial assets in the US during the 1980s and 1990s), and its payouts are much more volatile.

By measuring year-on-year changes in revenues and the two measures of fund returns, we calculate the volatility of these changes as seen in Table A2.1. The first column of the table shows that even unsmoothed payouts, based on historical nominal returns on financial assets, reduce the volatility of flows into the Treasury considerably compared to the alternative of simply paying the proceeds of resource taxation into general revenues.

Table A2.1: Standard Deviation of Year on Year Changes in Revenues and Fund Payouts

\begin{tabular}{lccc}
\hline & $\mathrm{US}^{1}$ & $\mathrm{UK}^{2}$ & World $^{3}$ \\
\hline Resource revenues & $1985-2010$ & $1985-2010$ & $1997-2010$ \\
Unsmoothed payouts & $35.2 \%$ & $36.5 \%$ & $35.8 \%$ \\
Smoothed payouts & $13.1 \%$ & $17.3 \%$ & $16.4 \%$ \\
\hline
\end{tabular}

Source: authors' calculations

Notes - Based on data on returns in: ${ }^{1}$ Damadoran (2014); ${ }^{2}$ Barclays; (2013); ${ }^{3}$ Dimson et al. (2002)

By way of comparison, the second column looks at the volatility of a fund based on the return on UK equities over the same period. The final column measures the volatility of a global portfolio over 1997-2010 (based on data on global returns in Dimson et al. 2002). The rankings of the different measures of the volatility of revenues and fund payouts are the same across the three columns, while the UK and World portfolios exhibit higher levels of volatility compared to the US. 


\section{Annex 3: Applying the 'permanent income hypothesis' approach to UK petroleum data}

The policy goal under the permanent income approach is to convert a finite stream of resource revenues derived from rents into a constant and permanent flow of income. We assume that resources are extracted from some initial date $t_{0}$ to the date of exhaustion $T$. The unit resource rent on extraction is denoted $n$, while the quantity extracted is $R$. Both $n$ and $R$ are assumed to be constant. For fixed interest rate $r$ the value of the resource asset at time $t$ is therefore,

$N(t)=\int_{t}^{T} n R \cdot e^{-r(s-t)} d s$

The permanent income approach assumes that some share of resource rents is transferred to general revenues at the Treasury, while the balance is invested in a natural resource fund yielding $r$. The funds invested in the natural resource fund are assumed to be equal to the instantaneous change in the value of the resource asset associated with current extraction $-\dot{N}(t)$.

The current transfer of resource revenues to the Treasury $Y_{R}(t)$ is therefore

$Y_{R}(t)=n R+\dot{N}(t)=r N(t)$

The value of the natural resource fund $A(t)$ is the cumulative sum of investments in the fund since the initiation of resource extraction,

$A(t)=\int_{t_{0}}^{t}-\dot{N}(s) d s=N\left(t_{0}\right)-N(t)$

The returns on the natural resource fund are paid to government general revenues, given by

$Y_{A}(t)=r \cdot\left(\left(N\left(t_{0}\right)-N(t)\right)\right.$

Therefore the total funds paid to government general revenues at time $t$ equal

$Y(t)=Y_{R}(t)+Y_{A}(t)=r \cdot N\left(t_{0}\right)$ 
The total payment to general revenues will therefore be constant over time. In practice the measured resource rent varies from year to year and this is replaced by the simple mean of resource rent,

$n R=\frac{\left.\sum_{s=t_{0}}^{T} n(s) R(s)\right)}{T-t_{0}}$

Similarly, resource tax revenues $V(t)$ will also vary over time and will generally be less than resource rent. We therefore adjust the values of $Y(t), Y_{R}(t)$ and $Y_{A}(t)$ by multiplying by the average ratio of tax revenues to resource rents, denoted $V^{*}$,

$V^{*}=\frac{\sum_{s=t_{0}}^{T} V(s)}{\sum_{s=t_{0}}^{T} n(s) R(s)}$

To compare the results between applying the bird in hand and permanent income approaches to managing petroleum revenues in the UK, Figure A3.1 plots the fund payments to general revenues under bird in hand (also presented in Figure 3 of the main text) and the separate payments from resource revenues $Y_{R}(t)$ and the natural resource fund $Y_{A}(t)$ as well as the total payments $Y(t)$ under the permanent income approach.

Common to both approaches, some portion of tax revenue is dedicated towards saving in a fund. In the case of the current figure this means not consuming much of the large revenues of the early to mid-1980s, in particular. However, the permanent income approach will direct a greater portion of tax revenues to government general receipts early in the depletion programme in contrast to the bird-in-hand approach. This has two (opposing) effects. It reduces the opportunity costs that Government would face in the 1980s under a bird-in-hand rule. But it also results in a smaller resource investment fund.

This is illustrated in Figure A3.2 which plots the total value of the natural resource funds accumulated under the bird-in-hand and permanent income approaches. By 2018 the permanent income approach yields a fund which is roughly half the size of the bird-in-hand fund. The figure also makes clear that the latter is considerably larger than the former over most of the period (at least as assumed in this comparison). This has the obvious 
consequences for the public sector balance sheet as discussed in Section 4.1 of the main text (Figure 5).

Figure A3.1: Resource Revenues and Returns from (Simulated) Bird-in-hand and Permanent Income SWFs (GBP millions, 2018)

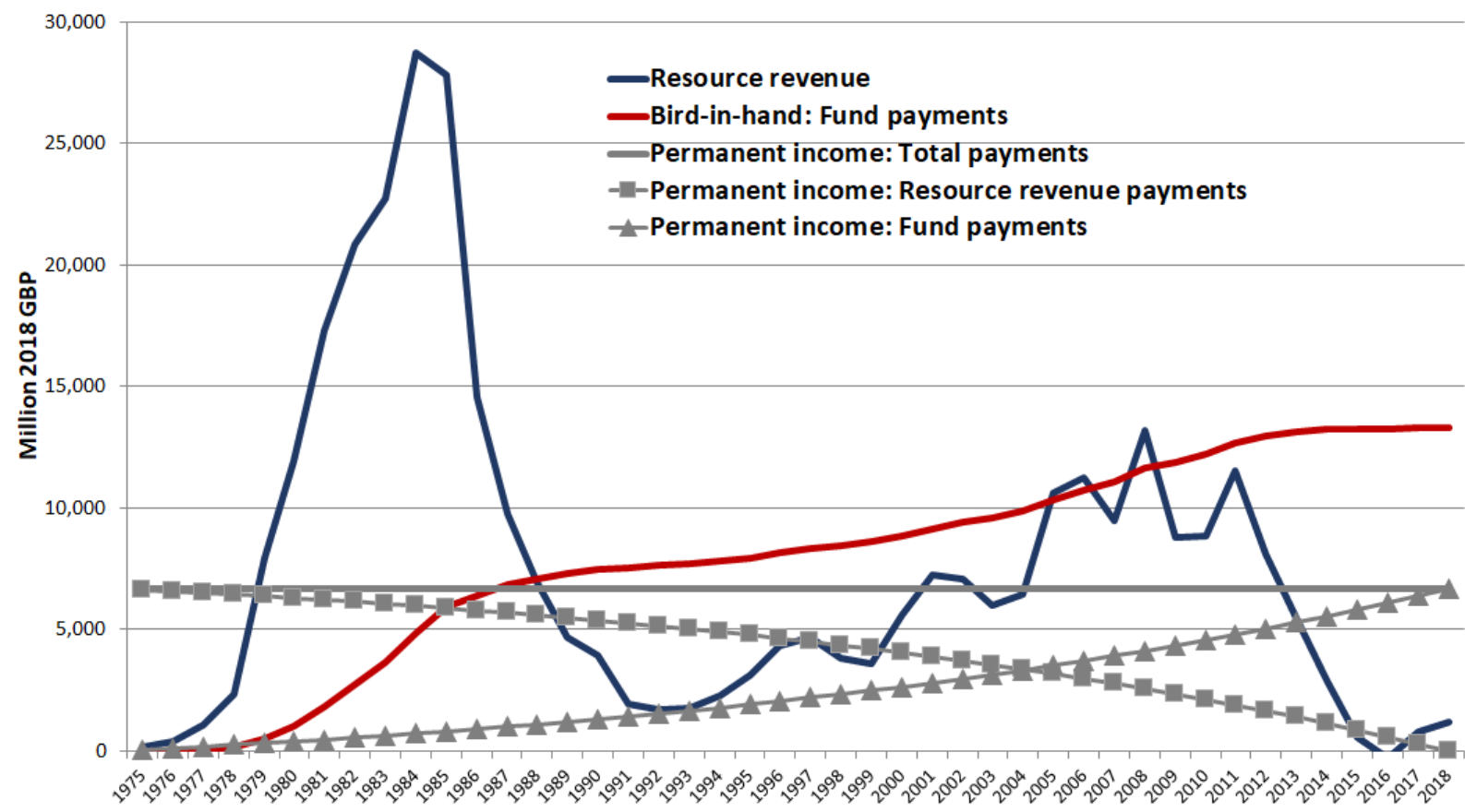

Source: OBR (various) and authors estimates

Figure A3.2: Total Value of (Simulated) Bird-in-hand and Permanent Income SWFs (GBP millions, 2018)

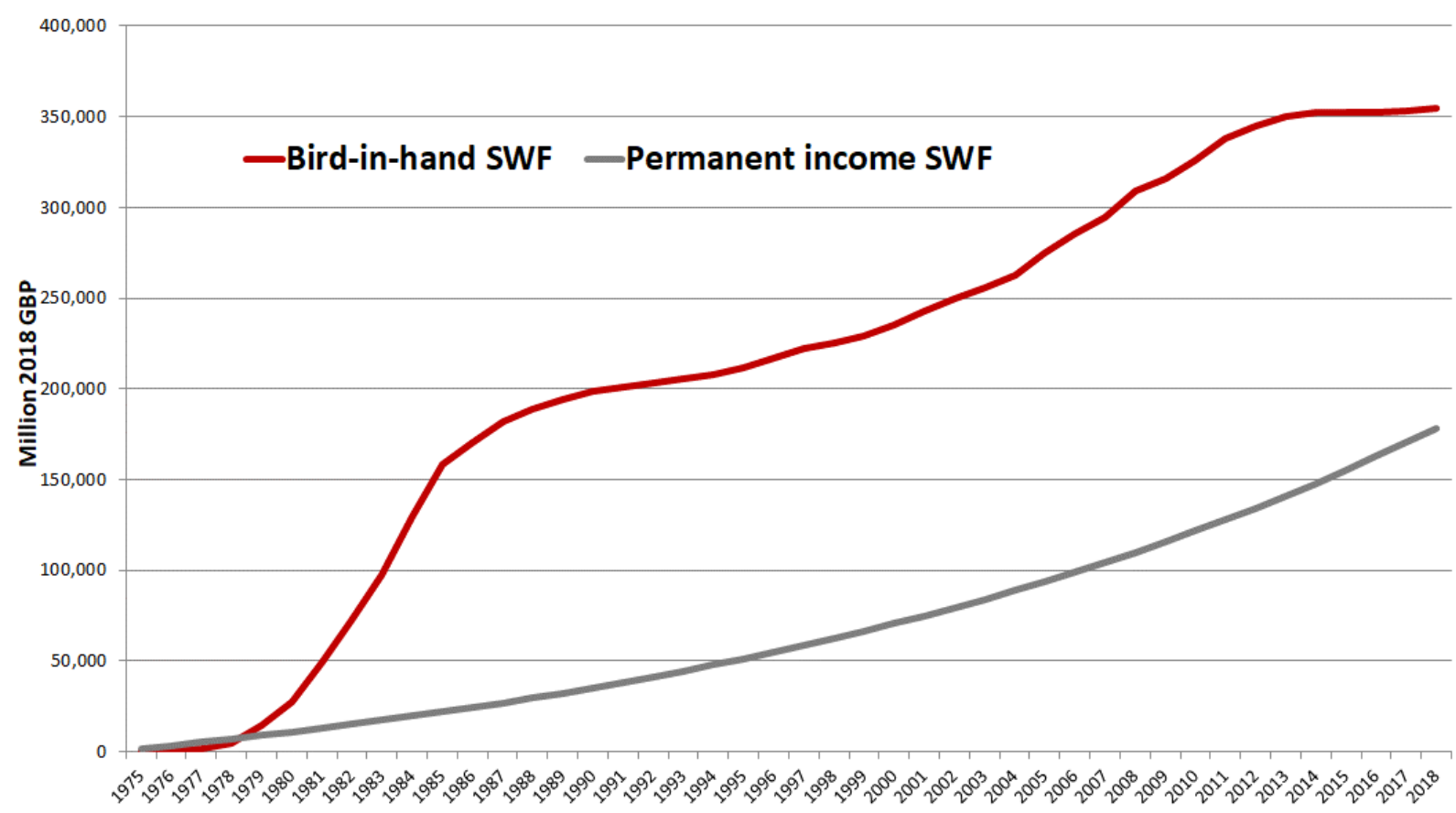

Source: OBR (various) and authors estimates 